This item was submitted to Loughborough's Research Repository by the author.

Items in Figshare are protected by copyright, with all rights reserved, unless otherwise indicated.

\title{
Board independence and firm value: A quasi-natural experiment using Taiwanese data
}

PLEASE CITE THE PUBLISHED VERSION

https://doi.org/10.1016/j.jempfin.2020.04.001

PUBLISHER

Elsevier

VERSION

AM (Accepted Manuscript)

PUBLISHER STATEMENT

This paper was accepted for publication in the journal Journal of Empirical Finance and the definitive published version is available at https://doi.org/10.1016/j.jempfin.2020.04.001.

LICENCE

CC BY-NC-ND 4.0

\section{REPOSITORY RECORD}

Fan, Yaoyao, Yuxiang Jiang, Mao-Feng Kao, and Hong Liu. 2020. "Board Independence and Firm Value: A Quasi-natural Experiment Using Taiwanese Data”. Loughborough University.

https://hdl.handle.net/2134/12111453.v1. 


\title{
Board independence and firm value: A quasi- natural experiment using Taiwanese data
}

\author{
Yaoyao Fan, Yuxiang Jiang ${ }^{\mathrm{b}, \mathrm{c}}$, Mao-Feng Kao ${ }^{\mathrm{d}}$, Frank Hong Liu ${ }^{\mathrm{e}}$
}

This version: 08.03.2020

\begin{abstract}
We examine the impact on firm value of independent directors based on Taiwanese firms. Using the changes in independent director composition mandated by the Amendments of Security and Exchange Act in Taiwan as a quasi-natural experiment, we document the arguably causal and negative effect of independent directors on firm value in both the short and long run. We also find that, in response to this act, firms have tended to replace existing non-independent directors, rather than simply adding new independent directors. We also find that the new independent directors have the same qualifications as those replaced non-independent directors but are costlier and busier. The evidence reflects the short supply of qualified independent directors and might explain the negative valuation effect.
\end{abstract}

Keywords: Independent directors; Firm value; Regulatory changes; Taiwanese firms

JEL Classification: G32; G38

a International School of Business \& Finance, Sun Yat-sen University, China

b Research Division, Galaxy Asset Management, China

c School of Business, East China University of Science and Technology, China

d Department of Accounting, National Dong Hwa University, Taiwan

e School of Business and Economics, Loughborough University, United Kingdom

* Corresponding author: Frank Hong Liu, School of Business and Economics, Loughborough University, Epinal Way, Loughborough Leicestershire, UK, LE11 3TU. E-mail address: H.H.Liu@ 1 boro.ac.uk (F.H. Liu). 


\section{Introduction}

After high-profile corporate scandals in the late 1990s and early 2000s, a wave of corporate governance reforms swept across the world, attracting much public, media and scholarly attention (Dahya and McConnell, 2007; Armstrong, Core, and Guay, 2014; Dah, Frye, and Hurst, 2014; Chen, Cheng, and Wang, 2015). Many countries passed regulations stipulating minimum levels for the representation of independent directors on the boards of listed firms. The introduction of such minimum standards triggered a dramatic increase in independent director representation. A presumption underlying this move toward a greater proportion of independent directors was that such directors could effectively increase the quality of boards' monitoring, and eventually increase firm value (Fama, 1980; Fama and Jensen, 1983).

Initially, some scholars found evidence to support this presumption. They found that firms with a higher proportion of independent directors paid CEOs higher equitybased compensation (Ryan and Wiggins, 2004) and were more likely to dismiss CEOs under poor firm performance (Cowen and Marcel, 2011); thus, such firms tended to exhibit higher firm value or profitability (Rosenstein and Wyatt, 1990; Jackling and Johl, 2009; Liang, Xu, and Jiraporn, 2013; Kim, Mauldin, and Patro, 2014; Coles, Daniel, and Naveen, 2007). However, other studies have disputed this presumption, reporting little or no correlation between board independence and firm value, and labelling greater board independence as mere window-dressing (Agrawal and Knoeber, 1996). Furthermore, several studies have provided evidence that board independence is negatively associated with firm value (Kiel and Nicholson, 2003; Gillette, Noe, and Rebello, 2007; Mangena, Tauringana, and Chamisa, 2012; Pathan and Faff, 2013). According to Donaldson (1990) and Donaldson and Davis (1991), compared to nonindependent directors who are insiders, independent directors, as outsiders, rarely understand a firm's business and operations, and this results in less effective strategic decisions being made and a reduction in firm value. 
Several reasons are presented below as to why the extant literature may fail to find a consistent relationship between board independence and firm value. First, board structures, including the appointments of independent directors, are not exogenous random variables (Hermalin and Weisbach, 1998; Harris and Raviv, 2006; Adams and Ferreira, 2007; Linck, Netter, and Yang, 2008; Sila, Gonzalez, and Hagendorff, 2016). Thus, the first endogeneity concern in relation to this topic is that independent directors and firm value are both affected by some unmeasured firm or year attributes (e.g. organizational or environmental uncertainty). The second endogeneity concern is that board independence results from firm value. Prior studies have documented that firms tend to add independent directors during periods of poor performance, in pursuit of social legitimacy (Westphal and Zajac, 1995a, 1995b). Second, the extant research has focused primarily on U.S. firms, whose boards have been dominated by independent directors for a relatively long period (Dahya and McConnell, 2007). Hence, the number of boards in the U.S. with no or few independent directors would be insufficient to serve as a control group. Additionally, boards in the U.S. rarely experience dramatic alterations, so the effect of changes in board independence on firm value is difficult to detect in such a context.

In this study, we further investigate the relationship between independent directors and firm value in a setting outside the U.S. In particular, our investigation covers Taiwan during the years with progressive enforcements of the new listing rule requiring that each firm's board have at least two independent directors, and that independent directors make up at least $20 \%$ of the board. Specifically, the regulators primarily imposed this requirement on firms applying for initial public offerings on the Taiwan Stock Exchange (TWSE) and the GreTai Securities Market (GTSM) in February 2002. Then, they gradually extended this requirement to listed firms with paid-up capital of more than 50 billion New Taiwan Dollars (NTD) in March 2006, those with more than 10 billion NTD in March 2011 and all listed firms in December 2013. Firms were required to comply with the requirement within three years after the compliance years. 
By employing Taiwanese firms in our study, we seek to avoid or at least mitigate some of the limitations of previous studies based on U.S. data. First, it is reasonable to assume that the new listing rule represents a staggered, relatively exogenous shock that changes board structure in Taiwan. Second, since the entire enforcement period lasted over a decade, the likelihood of new independent directors being appointed during a period of good firm performance and a period of bad firm performance is almost the same. This alleviates the reverse causality issue to some extent. Third, since firms of varying sizes were obliged to comply with the new rule at different times, it is easy to find sufficient boards with no or few independent directors as a control group. Fourth, as firms were required to comply with the new rule within a relatively short time period (three years), there is a large sample of boards with changed structures, thus enabling a clean before-and-after analysis.

The main question we address is whether firm value increases or decreases as a result of the new board structures mandated by the new regulations. Using a panel of 640 Taiwanese listed firms from 2000 to 2015, we find a significant negative impact arising from the regulation-induced changes of board independence on firm value. First, following Eckbo, Nygaard, and Thorburn (2019), we run an event study of stock price reaction to the announcements of major regulation-related news. As discussed in detail in Section 2 below, the announcements of the new regulations were made in some surprising manners, which generate relatively unanticipated news events. Overall, we find that the market reaction to regulation-related news events is negative. For instance, on the two days around the announcement of the first event in February 2002, we find an average abnormal stock return for all Taiwanese firms of $-0.9 \%$, which is statistically different from zero.

Moreover, we also conduct cross-sectional OLS regressions at firm level to examine whether the market reaction to the announcement events of the new regulations arose from a shortfall of independent directors. Independent director shortfall, labelled simply as Shortfall, is the difference between the percentage of 
independent directors required by the regulations and the actual percentage of independent directors. We find a negative impact of the regulation-induced independent director shortfall on the event returns for all five events. This impact is economically and statistically significant. For example, during the first event in February 2002, a $1 \%$ increase in the percentage of independent director shortfall is linked to $0.085 \%$ lower abnormal stock returns, equivalent to a loss of 11.59 million NTD in shareholder value. Thus, this evidence shows that the market reacts negatively to the appointments of independent directors shortly following the regulations.

Third, following Ahern and Dittmar (2012), we employ the two-stage instrumental variable (IV) method to investigate the arguably causal effect of the regulations on Tobin's Q during the long-term period when Taiwanese firms implemented the required board changes. Young, Tsai, and Hsieh (2008) and Chou, Hamill, and Yeh (2016) observed that while the first announcement event (February 2002) only obliged IPO firms to comply, several listed firms in Taiwan began voluntarily appointing independent directors shortly after that event. This phenomenon could be endogenous, since it might be a timing strategy of firms. Thus, in the first stage, we create an instrument designed to ease the effect of firm-specific (endogenous) compliance timing from 2002 to 2015. The instrument replaces the actual evolution of the firm's independent director shortfall with the market-wide compliance trend from a relatively exogenous, firm-specific starting point in 2001.

In the second stage, Tobin's $Q$ is regressed on the instrumented percentage of independent director shortfall, controlling for firm- and year-fixed effects. We find that independent director shortfall has a significant and positive impact on Tobin's Q. In terms of economic significance, one more independent director shortfall in number generally leads to an increase in Tobin's Q of 0.154 , which accounts for $13.17 \%$ of the sample mean. Our OLS regressions also provide the same evidence, although the estimation effect is lower. Since a higher shortfall means fewer independent directors, we conclude that the regulation-induced appointments of independent directors have a 
substantial negative impact on Tobin's Q. This conclusion is in line with that of the event study.

Fourth, following Matsa and Miller (2013), Armstrong, Core, and Guay (2014), Dah, Frye, and Hurst (2014) and Eckbo, Nygaard, and Thorburn (2019), we conduct a difference-in-difference test for the impact of the regulations on operating profitability, measured by ROA, to further check the consistency of prior findings. We find an obvious decrease in operating profitability during the post ASEA periods by compliant firms compared with firms that did not comply with the ASEAs. The economic impact is also significant. For instance, after the first ASEA, relative to non-compliant firms, compliant firms reduce their operating profitability by $1.04 \%$ in value, which accounts for $14.92 \%$ of the sample mean $(6.97 \%)$. This evidence shows that the mandatory increase in independent directors negatively impacts firm operating profitability, consistent with the findings on Tobin's Q.

We also conduct several robustness tests to check the validity of our difference-indifference (DID) results. We first construct a matched sample of compliant and noncompliant firms to exclude the alternative explanation that our DID results spuriously reveal differences in the characteristics of compliant and non-compliant firms, rather than the effect of the ASEA regulations per se on operating profitability. Second, we drop observations of firms with paid-up capital within a $10 \%$ band of the regulatory thresholds, as small margins above or below the regulatory thresholds might result from firm manipulation. In doing so, we can exclude the alternative explanation that our results could be driven by firms that tend to bypass the regulations via intentionally lowering their paid-up capital to just below the required thresholds. We lastly conduct two falsification tests by creating and applying 'pseudo-event' firms and 'pseudo-event' years respectively in our DID regressions. Our robustness-check findings further support our baseline ones. In sum, the regulations on independent director representation impose substantial costs on shareholders of Taiwanese firms in both the short and long term. 
To better understand the cause of firm value loss, following Ahern and Dittmar (2012) and Eckbo, Nygaard, and Thorburn (2019), we next examine how the regulations influence board characteristics, such as board size, education, experience, compensation and busyness. Specifically, we conduct a DID test for regulation-induced changes in board characteristics. Interestingly, we do not find that the regulations lead to changes in board size. This suggests that although a firm could have met the regulations by simply adding new independent directors, it is optimal to maintain board size even at the cost of replacing existing non-independent directors. We also find that despite having the same credentials with respect to education and experience, the new independent directors are more costly and busier than non-independent directors who have been replaced. This reveals the insufficient supply of qualified independent directors and might explain the significant adverse economic effect of the regulations.

This article contributes to the board governance literature in two ways. First, its primary contribution is to present relatively clean evidence on the value of board independence using a quasi-natural experiment. Other papers have investigated the impact of regulatory changes on board independence with respect to the Amendment of Korea's Corporate Governance Rules of 1999 (Black, Jang, and Kim, 2006; Choi, Park, and Yoo, 2007; Black and Kim, 2012); Clause 49 in India of 2000 (Black and Khanna, 2007); the Guidelines for Introducing Independent Directors to the Board in China of 2001 (Liu, Miletkov, Wei, and Yang, 2015); the Sarbanes-Oxley Act of 2002 in the U.S. (Bhagat and Bolton, 2013; Armstrong, Core, and Guay, 2014; Chen, Cheng, and Wang, 2015; Balsmeier, Fleming, and Manso, 2017); and the Cadbury Committee Report in the UK (Dahya and McConnell, 2007). By using one-time regulatory changes to board independence as shocks, the prior literature generally documents a positive causal impact of independent directors on firm value. Contrarily, using staggered regulatory changes to board independence in Taiwan as a single shock, our study reveals a negative and arguably causal impact. We also provide new evidence of the obvious increase in board compensation and busyness after the regulation compliances, 
which reflects the insufficient supply of qualified independent directors, to explain the negative valuation effect.

The article's second contribution is to add to the so-far limited literature on board independence in Taiwan. Prior studies have focused on the voluntary appointments of independent directors by Taiwanese listed firms before the first mandated implementation of the Amendment of Security and Exchange Act (ASEA) with respect to listed firms in 2006. These studies generally find a positive relationship between board independence and firm value (Luan and Tang, 2007; Young, Tsai, and Hsieh, 2008; Chou, Hamill, and Yeh, 2016). However, our study mainly focuses on the mandated, progressive appointments of independent directors by Taiwanese listed firms since the first ASEA in 2006. By exploring the staggered ASEAs as a quasi-natural experiment, our study establishes an arguably causal relationship between board independence and firm value. In contrast to prior findings, our study documents a negative relationship between board independence and firm value. Thus, our study has important implications for Taiwanese regulators and investors.

The remainder of this paper is structured as follows. Section 2 presents an introduction of board independence reform in Taiwan. Section 3 reports on our sample collection, selection and descriptive statistics. Section 4 shows the arguably causal impact of independent directors on firm value, while Section 5 shows the potential reasons behind independent directors' impact on firm value. Finally, Section 6 presents our conclusion.

\section{The timeline of board independence reform in Taiwan}

Since the 1997-1998 Asian financial crisis, many Eastern economies, such as those of China, South Korea, Malaysia, Singapore and Taiwan, aiming to improve board governance, have made it mandatory for firms to appoint a minimum number/ratio of independent directors (Black and Kim, 2012). Unlike some fellow 
Eastern countries that imposed this requirement on all listed firms at the same time, Taiwan enforced this requirement for different kinds of firms across different time periods, according to the paid-up capital of the listed firms. Thus, a sample taken exclusively from Taiwan provides us with a rare, quasi-experimental setting in which to assess the arguably causal effect of staggered, relatively exogenous changes in board structure on firm value.

We focus on the five event dates listed in Table 1, all of which reflect specific stages of this reform. The first event occurred on 22 February 2002, when both the TWSE and the GTSM introduced a new rule requiring that firms applying for initial public offerings (IPOs) appoint no fewer than two independent directors, and 20 per cent of boards (Event 1). The new rule also allowed all listed firms to appoint, or increase, the proportion of independent directors, on a voluntary basis. This mandatory change stirred serious doubts and intense debate among scholars and practitioners alike (Young, Tsai, and Hsieh, 2008; Chou, Hamill, and Yeh, 2016), many of whom were surprised by this regulatory development.

On 11 January 2006, the Amendment of Security and Exchange Act (ASEA) was introduced, requiring certain listed firms in Taiwan to meet certain minimum requirements relating to the number/proportion of independent directors on their boards (two members and 20\%) (Event 2). This suggests that Taiwanese regulators had written the independent director rule into corporate law, but nevertheless left room for listed firms to flexibly comply. Subsequently, on 28 March 2006, the Financial Supervisory Commission (FSC), essentially the TWSE authorities, imposed this act upon all public financial institutions, as well as listed firms in non-financial sectors with paid-up capital of more than 50 billion NTD (approximately US\$1.66 billion) (Event 3). On 22 March 2011, the FSC extended the ASEA to listed non-financial firms with paid-up capital of above 10 billion NTD (approximately US\$0.33 billion) (Event 4), and it extended the ASEA further to all listed firms on 31 December 2013 (Event 5). 
Firms must implement this act when the contract terms of their incumbent directors expire. For instance, if there is only one current director whose contract term is going to expire in the last month of the act enforcement years, the firm needs to comply with the ASEA by appointing one independent director by the first month of one year after the act enforcement years. Given the three-year election cycle of directors in Taiwanese firms, ${ }^{1}$ all listed firms in Taiwan should therefore have had at least two independent directors on their boards, and independent directors should have comprised 20 percent of their boards by 31 December 2016.

\section{[Insert Table 1 here]}

\section{Data and descriptive statistics}

In this section, we present the data sources and sample selection processes before discussing the statistics that describe firm value, firm characteristics and board characteristics in our sample.

\subsection{Data}

Our study sample is taken from a dataset of firms listed on the TWSE and the GTSM for the years 2000-2015. We obtained all data regarding financial statements, stock prices and board characteristics from the Taiwan Economic Journal (TEJ) database or through manual collection. To identify the effect of the independent director regulations on firm value, it was essential to obtain publicly observable share prices and accounting figures. Thus, although we collected the names of all Taiwanese listed firms from 2000 to 2015, we deleted firms that were newly listed after 22 February 2002 (the date of the first announcement of the rule) and firms with fewer than 100 daily stock return observations. We also excluded financial and public utility firms from our sample. To rule out noise from outliers, we winsorized all continuous variables at

\footnotetext{
1 See Paragraph 1 of Article 195 of the Compact Act.
} 
the $1 \%$ level. Our final dataset comprised 5,303 observations from firms that complied with the ASEAs at different dates between 2006 and 2015, and another 4,065 observations from firms not required to comply. Overall, our final sample consisted of 9,368 firm-year observations.

\subsection{Descriptive statistics}

Table 2 shows that the mandated percentage of independent directors depends upon board size and ranges from $20 \%$ to $40 \%$. For instance, a board in a Taiwanese firm composed of five directors must have a minimum independent director representation (two in number), while for a board with six members the requirement is $33 \%$ (two in number). Columns (3)-(5) of Table 2 report the percentage of new independent directors required by the regulations for a given board size, labelled as Shortfall. Throughout this paper, we employ Shortfall to measure the regulatory constraint faced by individual Taiwanese firms. As the required percentage of independent directors varies in line with board size, a firm can reduce Shortfall either by replacing existing non-independent directors or by changing board size. As shown in Table 2, increasing the board size from five to six members enables a firm to recruit two independent directors while still retaining its four existing non-independent directors. Meanwhile, reducing the board from eleven to ten members enables a firm to appoint two (rather than three) independent directors while retaining its eight nonindependent directors.

As shown in Figure 1, only $4.8 \%$ of the average board's directors were independent in 2000 and 2001, which is well short of the $20 \%$ minimum subsequently imposed by the regulation. This implies that the average Taiwanese firm, prior to the regulation, had a board in which almost all members were non-independent directors. Figure 2 also supports this observation by showing that, based on statistics for 2000 and 2001, the average Taiwanese firm needed to appoint more independent directors to comply with the incoming regulation. Figure 1 also depicts that the average Taiwanese 
board size was slightly smaller than ten directors in 2000 and 2001. Thus, theoretically speaking, a Taiwanese firm could have expanded its board size from ten to thirteen in order to retain all of its non-independent directors and simply appointed three new independent directors to comply with the act. However, this does not appear to have happened, as the average board size has remained at around ten directors across our sample period. This suggests that the perceived cost of enhancing board size is more than the expected benefit of retaining all existing non-independent directors.

Figure 1 also shows the mean of the number of independent directors on Taiwanese boards and the mean of the percentage of independent directors for each given year. Both indicators grew continuously during the sample period. In particular, board independence experienced an obvious increase after the ASEAs, indicating that Taiwanese firms have generally complied with the regulations. For instance, the percentage of independent directors almost doubled within two years of the ASEA's passage in 2006. Figures 3, 4 and 5 further support the effectiveness of the regulations by showing that the board independence of compliant firms significantly increased after the enforcements. For example, the percentage of independent directors of firms with paid-up capital of more than 50 billion NTD increased from $7.8 \%$ in 2006 to almost $20 \%$ in 2009. Despite this continued increase, the mean of the number of independent directors failed to reach the stipulated two, and that of the percentage of independent directors also failed to reach its target (20\%) during our sample period. Moreover, although Shortfall has been decreasing, it has not reached zero over the sample period. These two findings suggest that Taiwanese firms tend to appoint the mandated minimum percentage or number of independent directors, rather than appointing more independent directors.

Table 3 presents the mean values of firm characteristics and the board characteristics of total sample firms, compliant firms and non-compliant firms respectively. As two measures of independent directors, Shortfall has an average value of 0.138 , suggesting that the average board needs to increase its independent director 
representation by $13.80 \%$ to comply with the regulatory requirement. Meanwhile, Shortfall number $_{\text {has }}$ an average value of 1.337 , suggesting that the average board needs to appoint another one to two independent directors to comply with the regulatory requirement. The average Tobin's $Q$ is 1.169 and the average $R O A$ is around $6.97 \%$. An average board has around ten members, and around $40 \%$ of Taiwanese firms have CEOs who are also chairmen. The average firm size in Taiwan is around 15 billion NTD. Total debt accounts for around $40 \%$ of total assets, and shares owned by ultimate shareholders account for $11.67 \%$ of total shares. These results are similar to those reported by Young, Tsai, and Hsieh (2008) and Chou, Hamill, and Yeh (2016).

The last column of Table 3 shows the mean differences of firm and board characteristics between compliant and non-compliant firms. On average, compliant firms have only a slightly lower Tobin's Q, a larger board size, higher leverage and lower ownership percentage than non-compliant firms. There are no significant differences in ROA and CEO duality between compliant and non-compliant firms. These figures suggest that both kinds of firms are, overall, similar in terms of value, financial distress and governance. However, the average assets of compliant firms (20.4 billion NTD) are around three times those of non-compliant firms (7.8 billion NTD). This obvious difference could be attributable to the fact that throughout the sample period, the regulations primarily required larger listed firms to appoint more independent directors.

\section{[Insert Figure 1 here]}

[Insert Figure 2 here]

[Insert Figure 3 here]

[Insert Figure 4 here]

[Insert Figure 5 here]

[Insert Table 2 here] 


\section{[Insert Table 3 here]}

\section{Do independent directors impact firm value?}

We investigated whether the regulations have an arguably causal impact on firm value by taking three complementary steps. First, we calculated the stock market reaction to the five key events of board independence reform in Taiwan. Second, we estimated the impact of the regulations on Tobin's Q using pre-regulation independent director representation as a measure of relatively exogenous changes in boards as required by the regulations. Third, we estimated the impact of the regulations on operating profitability (ROA), employing a DID approach. The first step reveals the immediate stock price reaction, whereas the second and third steps provide a long-term view of the impact of the regulations on firm value.

\subsection{Stock price effect of the announcements of the five key events}

To investigate the market reaction to the board independence reform in Taiwan, we studied the five events outlined in Table 3 using daily stock returns for Taiwanese listed firms for the period of 2000-2015. Daily stock returns were calculated as the differences in daily closing prices, adjusted for splits and dividends. Following Brown and Warner (1980, 1985) and Eckbo, Nygaard, and Thorburn (2019), we employed the standard two-day event window, ending with the event announcement date (day 0), to boost test power. As each event affected certain firms simultaneously, we resolved the potential contemporaneous cross-correlation of stock returns by creating equalweighted calendar-time portfolios of the Taiwanese listed firms. Specifically, for each of the five events, $k=1, \ldots, 5$, we estimated the daily abnormal return parameter $A R_{k}$, using the following formula:

$$
R_{t}=\alpha+\beta R m t_{t}+A R_{k} D_{d k}+\varepsilon_{t}
$$


Where $R_{t}$ is the daily stock return to the Taiwanese listed firm, in excess of the daily three-month US Treasury bill, $R m t_{t}$ is the daily excess return on the TWII stock market index, and $D_{d k}$ is a dummy variable that equals one for each day in the twoday event window $(-1,0)$, and zero otherwise. Thus, the event parameter $A R_{k}$ is the average daily abnormal return over the two event days, and the two-day cumulative return is $\operatorname{CAR}(-1,0)=2 A R_{k}^{2}$.

Table 4 presents the results of the event study on the two-day abnormal returns with $p$-values. Column (1) contains the total sample of all listed firms in Taiwan, while Columns (2)-(3) contain the sub-samples of firms with High Shortfall and Low Shortfall respectively, measured at the calendar year prior to each event date. Column (4) uses the sub-sample of firms that are long in High Shortfall and short in Low Shortfall across the five event dates. Shortfall is defined as the difference between the percentage of independent directors required by the regulations and the actual percentage of independent directors on boards. High Shortfall are firms with Shortfall at or above the sample median in each calendar year, while Low Shortfall are those below the sample median.

In Column (1), we consistently observe significant and negative abnormal stock returns for all five events. For instance, we find an average abnormal stock return for all Taiwanese firms of $-0.9 \%$ for Event 1 and another mean of $-0.4 \%$ for Event 2, both statistically different from zero. In particular, firms witnessed the largest loss during the announcement of Event 4. The remaining columns reveal that these negative returns were driven by all firms, regardless of whether their Shortfall was high or low. Firms with High Shortfall, which would be more severely impacted by the reform, experienced average losses of $1.0 \%$ and $0.5 \%$ in the two-day window surrounding the announcement of Events 1 and 2 respectively, compared with losses of $0.7 \%$ and $0.2 \%$

\footnotetext{
2 The $t$-statistics of $C A R_{(-1,0)}=\frac{2 A R_{k}}{S D_{A R_{k}}}$. We use the 252 trading days before before event date $k$ (day 0 ), excluding days of previous events, if any, to compute $S D_{A R_{k}}$ (the standard deviation of $A R_{k}$ ).
} 
for those firms with Low Shortfall. Moreover, as shown in Appendix B, results for an alternative five-day event window $(-2,2)$ generated identical statistical inferences. ${ }^{3}$ In sum, the market reacted negatively to the announcements of the regulations.

We also conducted cross-sectional OLS regressions at the firm level to test whether the market reaction to the key announcement events of the new regulations resulted from a shortfall of independent directors. If the regulation-induced board changes in the future were costly, firm $i$ 's abnormal returns in response to event $k$, $C A R(-1,0)$, were expected to be more negative when there were more regulatory constraints (i.e. negatively related to Shortfall). For each event $k$, the regression specification is shown below:

$$
\operatorname{CAR}_{i, k}(-1,0)=\alpha_{k}+\beta_{1, k} \text { Shortfall }_{i, k}+\beta_{2, k} \text { Controls }_{i, k}+\text { Industry }_{i}+\varepsilon_{i, k}
$$

Where Controls $_{i, k}$ is a vector of control variables including Board Size (the total number of board directors), CEO Duality (a dummy variable that equals one if the CEO is also the chairman of the board), Total Assets (the log of total assets), Leverage (the debt-to-assets ratio), and Ownership \% (the percentage of shares owned by ultimate shareholders). All control variables are defined in Appendix A. Industry $y_{i}$ controls for industry-fixed effects. We also re-conducted these cross-sectional OLS regressions for the shortfall of independent directors (by number) by replacing Shortfall with Shortfall number $_{\text {in the equation above. }}$

Table 5 presents the cross-sectional OLS regression results. The results show a significant and negative effect of both Shortfall and Shortfall ${ }_{n u m b e r}$ on the firm returns for all five events. The economic significance here is not trivial. For instance, the coefficient in Column (1) revealed that a $1 \%$ increase in the percentage of independent

\footnotetext{
${ }^{3}$ Following Ahern and Dittmar (2012), we also find that the negative returns are driven by all firms, regardless of whether they have independent directors before the events. Firms with no independent directors experience greater return losses than ones with independent directors during the event announcements.
} 
director shortfall was associated with lower abnormal stock returns of $0.085 \%$, which is equivalent to a loss of 11.59 million NTD in shareholder value based on the average market capitalization of our sample firms (13.64 billion NTD). The coefficient in Column (2) reflects that the shortfall (in number) of one independent director is related to lower abnormal stock returns of $0.9 \%$, equivalent to a loss of 122.76 million NTD in shareholder value for an average firm (13.64 billion NTD). In other words, our findings show a larger decline in value for firms with a higher shortfall of independent directors, which were expected to recruit more independent directors shortly following the regulations. Therefore, the market perceived the mandated appointments of independent directors negatively. This further implies that the regulations imposed significant and costly constraints on Taiwanese firms.

\section{[Insert Table 4 here]}

\section{[Insert Table 5 here]}

\subsection{The impact of the regulations on Tobin's $Q$}

In this section, we examine the impact of the regulations on Tobin's $\mathrm{Q}$ during the long-term periods when Taiwanese firms executed the required board changes. If the market is efficient, the valuation effect of the market reaction to the regulation announcements should be unbiased (Eckbo, Nygaard, and Thorburn, 2019). This indicates that the Tobin's Q of the firm should undergo corresponding changes in the subsequent periods. Thus, to examine the specific effect, we, following Ahern and Dittmar (2012) and Eckbo, Nygaard, and Thorburn (2019), conducted reduced-form (OLS) regressions, along with two-stage instrumental variable (IV) analysis. Our OLS regressions based on an unbalanced panel of 640 listed firms in Taiwan over the period 2002-2015 are presented below:

$$
\text { Tobin's }_{i, t}=\alpha+\beta \text { Shortfall } i, t+\text { Firm }_{i}+\text { Year }_{t}+\varepsilon_{i, t}
$$


Where Tobin's $Q_{i, t}$ is defined as the sum of market value of equity and the book value of debt divided by the book value of assets, following Chou, Hamill, and Yeh (2016). Firm $i$ and Year $_{t}$ control for firm- and year-fixed effects respectively. We did not include control variables in the specification to avoid the potential problem of bad controls.

We then used the IV analysis to check the robustness of our results. In terms of motivation, both Young, Tsai, and Hsieh (2008) and Chou, Hamill, and Yeh (2016) show that while the first announcement event (22 February 2002) required only IPO firms to comply, several listed firms also began to voluntarily appoint independent directors shortly after that event. This phenomenon could be endogenous, as it might be a timing strategy of firms. Thus, the first-stage regressions in the IV analysis were used to mitigate the effect of firm-specific (endogenous) compliance timing during this thirteen-year compliance period. Specifically, we instrumented the percentage of independent director shortfall with the market-wide board trend from a firm-specific point in 2001, prior to the first announcement event in early 2002.

In the first stage, we regress Shortfall $_{i, t}$ on Shortfall $_{i, T_{0}}$ interacted with Year $_{t}$ (year dummies), as below:

$$
\text { Shortfall }_{i, t}=\alpha+\beta \text { Shortfall }_{i, T_{0}} \text { Year }_{t}+\text { Firm }_{i}+\text { Year }_{t}+\varepsilon_{i, t}
$$

Where Shortfall ST, $_{0}$ is firm $i$ 's (exogenous) regulation-induced shortfall of independent directors in fraction in base-year $T_{0}$. In the second stage, we regress Tobin's $Q_{i, t}$ on the predicted shortfall, Shortfall $l_{l, t}$, calculated from the first-stage regressions:

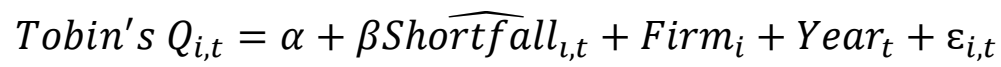

We also re-conducted this IV analysis for the shortfall of independent director by number by replacing Shortfall with Shortfall $l_{\text {number }}$ in the two equations above.

The results of the OLS regressions and the second-stage IV regressions are shown 
in Table 6, while those of the first-stage IV regressions are shown in Appendix C. In the first four columns of Table 6, the estimation period starts in 2002 and ends in 2009, when all the new independent directors in firms with paid-up capital of more than 50 billion NTD are in place. Meanwhile, the estimation sample includes all firms, because the independent director shortfall could apply to any firms during this period. The same logic applies to the estimation period of 2002-2013 and the corresponding estimation sample of firms with paid-up capital of less than 50 billion NTD in the middle four columns, and the estimation period of 2002-2015, alongside the corresponding estimation sample of firms with paid-up capital of less than 10 billion NTD in the last four columns. The OLS results are presented in the first two columns of each estimation period, while the second-stage IV results are presented in the last two columns of each estimation period. Since 2001 is the last year in which the cross-sectional distribution of independent directors is not impacted by the regulatory events, $T_{0}=2001$ across all columns.

The coefficients of the second-stage IV regressions on Shortfall and Shortfall number $_{\text {. }}$ are all positive and significant at the $5 \%$ level or above in Table 6 . This indicates a positive impact of the shortfall of independent directors (in fraction or in number) on firm value. In particular, the coefficient in Column (3) implies that a $10 \%$ increase in the percentage of independent director shortfall led to an increase in Tobin's Q of 0.170, compared to the mean of 1.169 across all firms and years. Moreover, the coefficient in Column (4) implies that one more independent director shortfall in number results in an increase in Tobin's Q of 0.154 , which accounts for $13.17 \%$ of the sample mean. Thus, the economic significance of independent director shortfall on firm value is obvious and great. Based on our definitions of Shortfall and Shortfall number $_{\text {(please see }}$ Appendix A), a higher shortfall of independent directors reflects fewer independent directors on boards. Thus, we conclude that the mandated increase of independent directors led to a decline in firm value, in line with the event-announcement results 
reported in the previous section. ${ }^{4}$

Consistent with the above findings, our OLS regression results also show a positive relationship between the shortfall of independent directors and firm value (Tobin's Q). However, OLS estimates of the coefficients on Shortfall and Shortfall number $_{\text {. }}$ were smaller and less significant than the IV estimates. This difference here suggests that, taking into account some endogenous factors, the IV regressions, compared to OLS regressions, could precipitate an estimate of a more causal effect of the shortfall of independent directors on firms. Additionally, the overall positive and significant coefficients in all columns of Appendix C suggest that independent director shortfall in 2001 was a strong predictor of the subsequent changes to independent director representation in Taiwanese firms, with large $F$-statistics suggesting strong explanatory power.

\section{[Insert Table 6 here]}

\subsection{The impact of the regulations on operating profitability (ROA)}

In the previous section, our empirical results show that the regulations have a negative impact on Tobin's Q, so in this section we investigate whether the impact of the regulations on firm operating profitability is consistent with that on Tobin's Q. Following Matsa and Miller (2013), Armstrong, Core, and Guay (2014), Dah, Frye and Hurst (2014), Chen, Cheng, and Wang (2015) and Eckbo, Nygaard, and Thorburn (2019), we employed a DID approach to estimate whether the regulation-induced variations in operating profitability for compliant firms (Events 3 and 4) differ from those of non-compliant firms by running the following OLS panel regressions:

\footnotetext{
${ }^{4}$ While not tabulated, we also use $T_{0}=2000$ as an alternative base year in regressions and generate consistent statistical inferences.
} 


$$
\begin{aligned}
\text { ROA }_{i, t}= & \alpha+\beta_{1} \text { Compliant Firms }_{i}+\beta_{2} \text { Post ASEA }_{t} \\
& +\beta_{3} \text { Compliant Firms }_{i} * \text { Post ASEA }_{t}+\beta_{4} \text { Controls }_{i, t}+\beta_{5} \text { Firm }_{i} \\
& +\beta_{6} \text { Year }_{t}+\varepsilon_{i, t}
\end{aligned}
$$

Where our dependent variable $R O A_{i, t}$ is defined as the ratio of earnings before interest and tax to total assets. For Event 3 (the first ASEA enforcement in 2006), Compliant Firms Fin $_{i}$ is a dummy variable that equals one for listed firms with paid-up capital of more than 50 billion NTD before 2006, and zero otherwise. We selected a five-year window for Event 3, which ranges from 2001 to 2010 (one year before the announcement of Event 4). Thus, Post $A S E A_{t}$ is a dummy variable that equals one if in the post ASEA period (2006-2010). For Event 4 (the second ASEA enforcement in 2011), Compliant Firms , $_{i}$ is a dummy variable that equals one for listed firms with paid-up capital ranging from 10 to 50 billion NTD before 2011, and zero for those with paid-up capital of less than 10 billion NTD. We selected a three-year window for Event 4, which ranges from 2008 to 2013 (around one year before the announcement of Event 5). Post $A S E A_{t}$ is a dummy variable that equals one if in the post ASEA period (2011-2013).

We included only firms for which we have at least one observation before and one after the enforcement year, respectively. $\beta_{1}$ captures the overall within-firm impact of independent directors on firm operating profitability, and $\beta_{2}$ captures the difference of firm operating profitability before and after the enforcements of the ASEAs. The datum with which this paper is particularly concerned, $\beta_{3}$, captures the incremental effect of the appointment of independent directors on firm operating profitability in the periods after the ASEAs are imposed on firms, compared with periods in which the firms were still free of the ASEA regulations. We also included a set of control variables, firm-fixed and year-fixed effects in our regressions.

We now turn to the DID regression results, as shown in Table 7. The first three columns and the last three columns report the regression results based on the first ASEA enforcement in 2006 and the second ASEA enforcement in 2011, respectively. Except 
those in Columns (1) and (4), regressions in the remaining columns adjust for both firmfixed and year-fixed effects. The dependent variable in Columns (3) and (6) is $R O A_{t+1}$, while in the remaining columns it is $R O A_{t}$. The negative coefficients for Post ASEA in Columns (1) and (4) indicate that after the implementations of the ASEAs, overall operating profitability witnessed an obvious decline, although the insignificant coefficients for Compliant Firms suggest that there was no difference in operating profitability between compliant and non-compliant firms.

Importantly, the empirical results across the six columns show a significant reduction in operating profitability during the post ASEA periods by compliant firms compared to firms that did not comply with the ASEAs, as indicated by the negative and significant coefficients on the interaction term Compliant Firms*Post ASEA at the $5 \%$ level or above. The economic magnitude is also nontrivial. Based on Columns (2) and (3), relative to non-compliant firms, compliant firms reduced their operating profitability by $1.04 \%$ and $1.15 \%$ in value, accounting for $14.92 \%$ and $16.50 \%$ of the sample mean (6.97\%), respectively. Thus, the evidence shows that the forced increase in independent directors negatively affected firm operating profitability, which is in line with the findings regarding Tobin's $Q$.

We then used several methods to check the robustness of our empirical results regarding operating profitability. First, we constructed a matched sample of compliant firms and non-compliant firms. By doing so, we could exclude the competing explanation that our results spuriously revealed differences in the characteristics of compliant firms and non-compliant firms, rather than the impact of the ASEA regulations per se on operating profitability. Using a one-to-one matching method without replacement, for each of the compliant firms we selected one non-compliant firm that was closest to the compliant firm based on observable characteristics during the pre-enforcement periods of the ASEAs. Specifically, the matching firm selected was the firm with the closest propensity score, estimated from a logit regression of compliant firms on a firm's board size, CEO duality, total assets, leverage, ownership \% 
and industry sector. This procedure resulted in a matched sample of 192 firms for the first ASEA in 2006, and 406 firms for the second ASEA in 2011, where the treatment and control groups were, overall, statistically indifferent based on firm and board characteristics, but not for firm size, which showed a weak significant difference (at the $10 \%$ level) (please see Appendix D). This evidence confirms the validity of our matching strategy. We then re-ran the regressions of Equation (6) using this newly matched sample.

Second, we dropped all firms with paid-up capital of within a band of $10 \%$ above or below the regulatory thresholds from our sample, since small margins above or below the regulatory thresholds might be the result of firm manipulation. By doing so, we could exclude the confounding explanation that our results might have been driven by firms which did not want to lose control of their boards and, thus, tried to bypass the regulations by reducing their paid-up capital to just below mandated thresholds. Our new sample contained 5,487 observations for the first ASEA implementation in 2006, and 2,674 observations for the second ASEA implementation in 2011. We then re-ran the regressions of Equation (6) using this new sample, which excluded firms with paidup capital close to the regulatory thresholds.

Third, to further mitigate concerns that alternative factors may have driven the impact of the regulations on operating profitability, we conducted two falsification tests. Our first falsification test involved creating 'pseudo-event' firms with paid-up capital ranging from 40 to 50 billion NTD before the first ASEA, and from 8 to 10 billion NTD before the second ASEA. We excluded firms actually compliant to these two ASEA enforcements. Our new sample thus contained 4,814 and 1,632 observations for the first and second ASEA implementations, respectively. We then re-ran regressions of Equation (6) by redefining the indicator Compliant Firms as Pseudo-event Firms. We conducted the second falsification test by generating 'pseudo-event' years, one year before the actual years in which the ASEAs began to apply to the firms in question. We 
then re-ran regressions of Equation (6) by replacing the indicator Post ASEA with Pseudo-post ASEA.

Tables 8 and 9 report our robustness estimation results regarding the arguably causal relationship between the ASEA-induced changes of independent directors and operating profitability. Specifically, Table 8 reports results using the matched sample and the sample that excludes firms with paid-up capital close to the regulatory thresholds, and Table 9 reports results using 'pseudo-event' firms and 'pseudo-event' years, respectively. As shown in Panels A and B of Table 8, the coefficients on the interaction term Compliant Firms *Post ASEA remain negative and significant at the 5\% level or above, suggesting that, after the ASEAs, compliant firms witnessed a more obvious decrease in operating profitability compared to their counterparts. These results indicate that our baseline results do not suffer from the possibility that the negative effect is due to the differing characteristics between compliant firms and their counterparts, rather than the ASEA regulations per se, and also the possibility that some firms manipulate their paid-up capital to avoid the regulations. As shown in Panels A and B of Table 9, the coefficients on the interaction term Pseudo-event Firms*Post ASEA and those on Compliant Firms*Pseudo-post ASEA are not statistically significant, suggesting that our results are not driven by alternative factors. Overall, our robustnesscheck evidence implies that the introductions of the ASEAs are behind our baseline findings.

In sum, the results in Section 4 suggest that the regulations on independent director representation imposed substantial costs on the shareholders of Taiwanese firms. Firms with a higher shortfall of independent directors, which would have been more influenced by the regulations, experienced a more obvious decrease in value (CAR) on the announcement dates of the regulations. The forced addition of new independent directors to boards led to losses in firm value in terms of both Tobin's Q and operating profitability, demonstrating that the negative effect of independent directors on firm value was persistent across time. 


\section{[Insert Table 7 here]}

\section{[Insert Table 8 here]}

\section{[Insert Table 9 here]}

\section{How did the regulations impact firm value?}

In this section, in the spirit of Ahern and Dittmar (2012) and Eckbo, Nygaard, and Thorburn (2019), we attempt to identify the regulation-induced variations in board characteristics, such as board size, education, experience, compensation and busyness, that may have led to the loss in firm value. The rationale is that although the regulations only mandate independent director representation, they may impose de facto limits on other board characteristics, simply because the pool of independent directors and nonindependent directors might have differed with respect to other dimensions. But did the regulation-induced loss of firm value result from increasing board size in order to retain all existing non-independent directors, from appointing relatively less qualified independent directors, or from a shortage of qualified independent directors in the market? To explore these questions, we employed the DID approach to test whether the regulation-induced changes in board characteristics for compliant firms (Events 3 and 4) differed from those of non-compliant firms by running the following OLS panel regressions:

\section{Board Characteristics $i, t$}

$$
\begin{aligned}
& =\alpha+\beta_{1} \text { Compliant Firms }_{i}+\beta_{2} \text { Post ASEA }_{t} \\
& +\beta_{3} \text { Compliant Firms }_{i} * \text { Post ASEA }_{t}+\beta_{4} \text { Controls }_{i, t}+\beta_{5} \text { Firm }_{i} \\
& +\beta_{6} \text { Year }_{t}+\varepsilon_{i, t} \quad \text { (7) }
\end{aligned}
$$

Where our dependent variable Board Characteristics ${ }_{i, t}$ includes Board Size, Board Education, Board Experience, Board Compensation and Board Busyness. Board Size is defined as the total number of board directors. Board Education is defined as the average education level of board directors (the education levels for each director 
were classified as follows: Bachelor's degree (1), Master's degree (2), $\mathrm{PhD}(3)$, and otherwise (0)). Board Experience is defined as the percentage of directors that are financial, accounting or legal experts. We classified a director as a financial or accounting expert if he or she: (i) had work experience in a banking institution; (ii) had work experience in a non-banking institution; and (iii) previously held a finance- or accounting-related role within a non-financial firm (e.g., CFO, accountant, auditor, treasurer or vice-president of finance and accounting). We classified a director as a legal expert if he or she had work experience as a legal counsel, attorney or judge.

Board Compensation is defined as the logarithm of the average compensation (salaries plus bonuses) of a board. Board Busyness is defined as the percentage of directors with at least two board seats. The definitions regarding Compliant Firms C $_{i}$ and Post ASEA $A_{t}$ are the same as those in Equation (6). As our primary interest, $\beta_{3}$, captures the incremental effect of the appointment of independent directors on board characteristics in the periods after the ASEA was imposed, compared to post periods in which the firms escape from the ASEA regulations. We also include a battery of control variables, firm-fixed and year-fixed effects in our regressions.

The DID regression results regarding the regulation-induced changes in board characteristics are presented in Table 10. Columns (1)-(4) show the impact of the first ASEA enforcement in 2006 on board size, board education, board experience and board compensation, respectively, while Columns (5)-(8) show the impact of the second enforcement in 2011. Column (9) displays the second ASEA-induced impact on board busyness, while the first ASEA-induced impact is not available here as the related data were only attainable from 2008. In Columns (1) and (5), the interaction variable Compliant Firms*Post ASEA is statistically insignificant. This suggests that the regulations did not cause changes in board size during the post ASEA periods by compliant firms compared to any firms that were not subject to the ASEAs. Thus, compliant firms tended to replace existing non-independent directors with new independent directors rather than keep the existing non-independent directors and hire 
additional independent directors, as a result of the regulations. Figure 1 also shows that the average board size remained largely unchanged across the time period of 2000 $2015 .^{5}$

In Columns (3), (6) and (7), the coefficient estimates for Compliant Firms*Post ASEA are statistically insignificant, although the estimate in Column (2) is positive and significant at the $10 \%$ level (statistically weak). These estimates indicate that there was, overall, no difference between compliant firms and non-compliant firms in terms of board education and experience after ASEA compliance. In other words, the regulationinduced new independent directors tended to have the same qualifications as the existing non-independent directors being replaced. In Columns (4), (8) and (9), the coefficient estimates for Compliant Firms*Post ASEA are all statistically significant at the $5 \%$ level or above. This suggests that compliant firms pay more compensation to directors and use busier directors after ASEA compliance than non-compliant firms. Thus, new independent directors tended to be more costly and busier than their replaced non-independent counterparts, suggesting that qualified independent directors were in short supply.

Overall, the evidence shows that firms tended to comply with the regulations by recruiting new independent directors to replace some of their existing non-independent directors. Specifically, we find that despite having the same qualifications, the new independent directors tended to ask for higher salaries and commit less time to the role than the replaced non-independent directors. This trend implies a shortage of qualified independent directors, which might in turn explain why we found a significant adverse economic effect of the regulations.

\section{[Insert Table 10 here]}

\footnotetext{
5 Figure 3, 4 and 5 also show the same evidence for firms with paid-up capital of more than 50 billion NTD, 10-50 billion NTD and less than 10 billion NTD across the time period, respectively.
} 


\section{Conclusion}

Based exclusively on Taiwanese data, our article investigates the effect of independent directors on firm value, a matter which has been the focus of much attention in recent years. Employing staggered regulatory changes to board independence imposed by the Amendment of Security and Exchange Act (ASEA) in Taiwan as a single shock, our study finds an arguably causal and negative relationship between board independence and firm value.

Specifically, we first conducted an event study and found a negative market reaction to regulation-related news events. Second, we conducted cross-sectional OLS regressions and found that the market reacted more negatively to firms that were expected to increase their independent director representation as required by the new regulations. Third, we employed the two-stage instrumental variable (IV) method and found that the mandated increase of independent directors had a significantly negative impact on Tobin's Q. Fourth, we conducted a DID test and observed an obvious reduction in operating profitability during the post ASEA periods by compliant firms compared with firms that did not need to follow the ASEAs. Our DID results were consistent under several robustness checks. In sum, these findings consistently show the negative impact of independent directors on firm value.

To better understand the underlying reasons behind the value loss, we attempted to identify the variations in board characteristics after regulation compliance. It seems that firms preferred to replace their existing non-independent directors with new independent directors, rather than simply add a sufficient number of new independent directors to the existing non-independent directors. Despite having the same credentials in terms of education and experience, the new independent directors seem to be more costly and busier than the replaced non-independent directors. This indicates that qualified independent directors are in short supply in the market, and it might explain the significant adverse economic effect of the regulations. Our study complements the 
extant literature on board governance reforms all over the world, while also adding to the so-far limited literature on board independence in Taiwan, providing important guidelines for Taiwanese regulators and investors. 


\section{References}

Adams, R. B., Ferreira, D., 2007. A theory of friendly boards. The Journal of Finance 62(1), 217-250.

Agrawal, A., Knoeber, C. R., 1996. Firm performance and mechanisms to control agency problems between managers and shareholders. Journal of Financial and Quantitative Analysis 31(3), 377-397.

Ahern, K. R., Dittmar, A. K., 2012. The changing of the boards: The impact on firm valuation of mandated female board representation. The Quarterly Journal of Economics 127(1), 137-197.

Armstrong, C. S., Core, J. E., Guay, W. R., 2014. Do independent directors cause improvements in firm transparency? Journal of Financial Economics 113(3), 383403.

Balsmeier, B., Fleming, L., Manso, G., 2017. Independent boards and innovation. Journal of Financial Economics 123(3), 536-557.

Bhagat, S., Bolton, B., 2013. Director ownership, governance, and performance. Journal of Financial and Quantitative Analysis 48(1), 105-135.

Black, B. S., Jang, H., Kim, W., 2006. Does corporate governance predict firms' market values? Evidence from Korea. The Journal of Law, Economics, and Organization 22(2), 366-413.

Black, B. S., Khanna, V. S., 2007. Can corporate governance reforms increase firm market values? Event study evidence from India. Journal of Empirical Legal Studies 4(4), 749-796.

Black, B., Kim, W., 2012. The effect of board structure on firm value: A multiple identification strategies approach using Korean data. Journal of Financial Economics 104(1), 203-226. 
Brown, S. J., Warner, J. B., 1980. Measuring security price performance. Journal of Financial Economics 8, 205-258.

Brown, S. J., Warner, J. B., 1985. Using daily stock returns: The case of event studies. Journal of Financial Economics 14, 3-31.

Chen, X., Cheng, Q., Wang, X., 2015. Does increased board independence reduce earnings management? Evidence from recent regulatory reforms. Review of Accounting Studies 20(2), 899-933.

Choi, J. J., Park, S. W., Yoo, S. S., 2007. The value of outside directors: Evidence from corporate governance reform in Korea. Journal of Financial and Quantitative Analysis 42(4), 941-962.

Chou, H. I., Hamill, P. A., Yeh, Y. H., 2018. Are all regulatory compliant independent director appointments the same? An analysis of Taiwanese board appointments. Journal of Corporate Finance, 50, 371-387.

Coles, J. L., Daniel, N. D., Naveen, L., 2008. Boards: Does one size fit all? Journal of Financial Economics 87(2), 329-356.

Cowen, A. P., Marcel, J. J., 2011. Damaged goods: Board decisions to dismiss reputationally compromised directors. Academy of Management Journal 54(3), 509-527.

Dah, M. A., Frye, M. B., Hurst, M., 2014. Board changes and CEO turnover: The unanticipated effects of the Sarbanes-Oxley Act. Journal of Banking \& Finance 41, 97-108.

Dahya, J., McConnell, J. J., 2007. Board composition, corporate performance, and the Cadbury committee recommendation. Journal of Financial and Quantitative Analysis 42(3), 535-564. 
Donaldson, L., 1990. The ethereal hand: Organizational economics and management theory. Academy of Management Review 15, 369-381.

Donaldson, L., Davis, J. H., 1991. Stewardship theory or agency theory: CEO governance and shareholder returns. Australian Journal of Management 16(1), 4964.

Eckbo, B. E., Nygaard, K., Thorburn, K. S., 2019. Board gender-balancing and firm value. Unpublished Finance Working Paper. European Corporate Governance Institute (ECGI).

Fama, E. F., 1980. Agency problems and the theory of the firm. Journal of Political Economy 88(2), 288-307.

Fama, E. F., Jensen, M. C., 1983. Agency problems and residual claims. Journal of Law and Economics 26(2), 327-349.

Gillette, A. B., Noe, T. H., Rebello, M. J., 2007. Board structures around the world: An experimental investigation. Review of Finance 12(1), 93-140.

Harris, M., Raviv, A., 2006. A theory of board control and size. The Review of Financial Studies 21(4), 1797-1832.

Hermalin, B. E., Weisbach, M. S., 1998. Endogenously chosen boards of directors and their monitoring of the CEO. American Economic Review 96-118.

Jackling, B., Johl, S., 2009. Board structure and firm performance: Evidence from India's top companies. Corporate Governance: An International Review 17(4), 492-509.

Kiel, G. C., Nicholson, G. J., 2003. Board composition and corporate performance: How the Australian experience informs contrasting theories of corporate governance. Corporate Governance: An International Review 11(3), 189-205. 
Kim, K., Mauldin, E., Patro, S., 2014. Outside directors and board advising and monitoring performance. Journal of Accounting and Economics 57(2-3), 110-131.

Liang, Q., Xu, P., Jiraporn, P., 2013. Board characteristics and Chinese bank performance. Journal of Banking \& Finance 37(8), 2953-2968.

Linck, J. S., Netter, J. M., Yang, T., 2008. The determinants of board structure. Journal of Financial Economics 87(2), 308-328.

Liu, Y., Miletkov, M. K., Wei, Z., Yang, T., 2015. Board independence and firm performance in China. Journal of Corporate Finance 30, 223-244.

Luan, C. J., Tang, M. J., 2007. Where is independent director efficacy? Corporate Governance: An International Review 15(4), 636-643.

Mangena, M., Tauringana, V., Chamisa, E., 2012. Corporate boards, ownership structure and firm performance in an environment of severe political and economic crisis. British Journal of Management 23, 23-41.

Matsa, D. A., Miller, A. R., 2013. A female style in corporate leadership? Evidence from quotas. American Economic Journal: Applied Economics 5(3), 136-69.

Pathan, S., Faff, R., 2013. Does board structure in banks really affect their performance? Journal of Banking \& Finance 37(5), 1573-1589.

Rosenstein, S., Wyatt, J. G., 1990. Outside directors, board independence, and shareholder wealth. Journal of financial economics 26(2), 175-191.

Ryan Jr, H. E., Wiggins III, R. A., 2004. Who is in whose pocket? Director compensation, board independence, and barriers to effective monitoring. Journal of Financial Economics 73(3), 497-524.

Sila, V., Gonzalez, A., Hagendorff, J., 2016. Women on board: Does boardroom gender diversity affect firm risk? Journal of Corporate Finance 36, 26-53. 
Westphal, J., Zajac, E., 1995a. Accounting for explanations of CEO compensation: substance and symbolism. Administrative Science Quarterly 40(2), 283-308.

Westphal, J., Zajac, E., 1995b. Who shall govern? CEO/board power, demographic similarity, and new director selection. Administrative Science Quarterly 40(1), 6083.

Young, C. S., Tsai, L. C., Hsieh, P. G., 2008. Voluntary appointment of independent directors in Taiwan: Motives and consequences. Journal of Business Finance \& Accounting 35(9-10), 1103-1137. 


\section{Table 1}

\section{Timeline of regulatory events}

This table shows the timeline of key events related to the announcements of independent director regulations.

(1) February 22, 2002: the Taiwan Stock Exchange (TWSE) and the GreTai Securities Market (GTSM) launch a new rule that requires firms applying for initial public offerings (IPOs) to appoint no fewer than two independent directors, or 20 per cent of boards if more.

(2) January 11, 2006: the Taiwanese regulators launch the Amendment of Security and Exchange Act (ASEA) requiring certain listed firms to appoint independent directors, not fewer than two in number and not less than one-fifth of boards. Without specifying compliant firms, this act still leaves room for listed firms to flexibly execute.

(3) March 28, 2006: the Financial Supervisory Commission (FSC), the Taiwanese stock exchange authority, applies the ASEA to all public financial institutions, such as financial holding firms, banks, bill-finance firms, insurance firms and securities firms, and also listed firms in the nonfinancial sectors having paid-up capital of more than 50 billion NTD (approximately US\$1.66 billion).

(4) March 22, 2011: the FSC extends the ASEA to listed non-financial firms with paid-up capital of above 10 billion NTD (approximately US $\$ 0.33$ billion).

(5) December 31, 2013: the FSC extends the ASEA to all listed firms. 
Table 2

Independent directors required by Taiwanese regulators

This table shows how the required number and percentage of independent directors varies with board size. Shortfall is the percentage of additional independent directors required to comply with the regulations for a given board size.

\begin{tabular}{cccccc}
\hline & & & \multicolumn{3}{c}{ Shortfall on board with } \\
\cline { 3 - 6 } Board size & $\begin{array}{c}\text { Required } \\
\text { number of } \\
\text { independent } \\
\text { directors }\end{array}$ & $\begin{array}{c}\text { Required } \\
\text { percentage of } \\
\text { independent } \\
\text { directors }\end{array}$ & $\begin{array}{c}\text { 0 independent } \\
\text { director }\end{array}$ & $\begin{array}{c}1 \text { independent } \\
\text { director }\end{array}$ & $\begin{array}{c}2 \text { independent } \\
\text { directors }\end{array}$ \\
& $(1)$ & $(2)$ & $(3)$ & $(4)$ & $(5)$ \\
\hline 5 & 2 & 0.40 & 0.40 & 0.20 & 0 \\
6 & 2 & 0.33 & 0.33 & 0.17 & 0 \\
7 & 2 & 0.29 & 0.29 & 0.14 & 0 \\
8 & 2 & 0.25 & 0.25 & 0.13 & 0 \\
9 & 2 & 0.22 & 0.22 & 0.11 & 0 \\
11 & 2 & 0.20 & 0.20 & 0.10 & 0 \\
$>11$ & 3 & 0.27 & 0.27 & 0.18 & 0.09 \\
\hline
\end{tabular}


Table 3

\section{Summary statistics}

This table reports descriptive statistics for the variables of 640 listed firms in Taiwan during the period of 2000 to 2015. Measures of firm value, independent directors and other control variables are described in Section 4.1 and Appendix A.

\begin{tabular}{|c|c|c|c|c|c|c|c|}
\hline \multirow[b]{2}{*}{ Variable } & \multicolumn{2}{|c|}{$\begin{array}{c}\text { Total firms }(9,368 \\
\text { observations })\end{array}$} & \multicolumn{2}{|c|}{$\begin{array}{c}\text { Compliant firms }(5,303 \\
\text { observations })\end{array}$} & \multicolumn{2}{|c|}{$\begin{array}{l}\text { Firms not required to comply } \\
(4,065 \text { observations })\end{array}$} & \multirow[b]{2}{*}{ Mean Difference } \\
\hline & Mean & SD & Mean & SD & Mean & SD & \\
\hline Shortfall & 0.138 & 0.145 & 0.106 & 0.128 & 0.180 & 0.134 & $-0.074 * * *$ \\
\hline Shortfall $_{\text {number }}$ & 1.337 & 1.169 & 0.981 & 1.165 & 1.801 & 1.175 & $-0.820 * * *$ \\
\hline Tobin's Q & 1.169 & 8.223 & 1.164 & 1.027 & 1.176 & 1.493 & $-0.012 * *$ \\
\hline ROA (\%) & 6.972 & 8.145 & 6.915 & 8.086 & 7.047 & 8.229 & -0.132 \\
\hline Board Size & 9.457 & 2.775 & 9.558 & 2.661 & 9.325 & 2.926 & $0.233 * * *$ \\
\hline CEO Duality & 0.382 & 0.729 & 0.380 & 0.722 & 0.384 & 0.738 & -0.004 \\
\hline Total Assets (Billion) & 14.967 & 41.194 & 20.428 & 49.817 & 7.843 & 21.646 & $12.585 * * *$ \\
\hline Total Assets (Log) & 10.283 & 1.400 & 10.343 & 1.522 & 10.205 & 1.146 & $0.138 * * *$ \\
\hline Leverage & 0.415 & 0.176 & 0.428 & 0.172 & 0.398 & 0.179 & $0.030 * * *$ \\
\hline Ownership \% & 11.670 & 12.769 & 11.109 & 12.408 & 12.403 & 13.233 & $-1.294 * * *$ \\
\hline
\end{tabular}




\section{Table 4}

\section{Abnormal stock returns to Taiwanese listed firms on two-day window of key event dates}

This table presents cumulative abnormal returns, $\operatorname{CAR}(-1,0)=2 A R_{k}$, for portfolios of Taiwanese listed firms on the key event date $k$, estimated using the calculation formula below:

$$
R_{t}=\alpha+\beta R m t_{t}+A R_{k} D_{d k}+\varepsilon_{t}
$$

Where, $R_{t}$ is the daily stock return to the Taiwanese listed firm, in excess of the daily three-month US Treasury bill, $R m t_{t}$ is the daily excess return on the TWII stock market index, and $D_{d k}$ is a dummy variable that equals 1 for each day in the two-day event window $(-1,0)$ and 0 otherwise. $A R_{k}$ is the average daily abnormal return over the two event days. Events $k=1, \ldots, 5$ are defined in Table 1. High Shortfall are firms with Shortfall (the percentage of new independent directors required to comply with the regulations) at or above the sample median in the calendar year prior to the event, while Low Shortfall are those below the sample median. High-Low is firms that are long in High Shortfall and are short in Low Shortfall. *,**, *** denote statistical significance at the $10 \%, 5 \%$ and $1 \%$ levels, respectively.

All firms High shortfall Low shortfall High-Low

(1)

(2)

(3)

(4)

(1) February 22, 2002: IPO firms

$C A R_{I}(-1,0)=2 A R_{I}$

$-0.009 * * *$

$-0.010 * * *$

$-0.007 * * *$

$-0.003 * * *$

$p$-value

$(0.001)$

$(0.001)$

$(0.003)$

(0.006)

$N$ (firms)

640

563

77

(2) January 11, 2006: the Amendment of Security and Exchange Act (ASEA)

$\begin{array}{lcccc}C A R_{2}(-1,0)=2 A R_{2} & -0.004 * * * & -0.005 * * * & -0.002 * * * & -0.003 * * \\ p \text {-value } & (0.003) & (0.004) & (0.009) & (0.035) \\ N \text { (firms) } & 640 & 534 & 106 & \end{array}$

(3) March 28, 2006: firms with paid-up capital of more than 50 billion NTD

$\begin{array}{lcccc}C A R_{3}(-1,0)=2 A R_{3} & -0.009^{* *} & -0.009^{* *} & -0.008^{* *} & -0.001^{*} \\ p \text {-value } & (0.041) & (0.035) & (0.011) & (0.060) \\ N \text { (firms) } & 106 & 83 & 23 & \end{array}$

(4) March 22, 2011: firms with paid-up capital of 10 50 billion NTD

$\begin{array}{lcccc}C A R_{4}(-1,0)=2 A R_{4} & -0.016^{* *} & -0.018^{* *} & -0.010^{*} & -0.008 \\ p \text {-value } & (0.045) & (0.042) & (0.067) & (0.112)\end{array}$

$N$ (firms)

232

178

54

(5) December 31, 2013: firms with paid-up capital of less than 10 billion NTD

\begin{tabular}{lcccc}
$C A R_{5}(-1,0)=2 A R_{5}$ & $-0.005^{* *}$ & $-0.006^{* *}$ & $-0.003^{* *}$ & $-0.003^{* *}$ \\
$p$-value & $(0.038)$ & $(0.032)$ & $(0.040)$ & $(0.039)$ \\
$N$ (firms) & 302 & 220 & 82 & \\
\hline
\end{tabular}




\section{Table 5}

\section{Cross-sectional regressions for announcement returns of key events}

This table presents the results of cross-sectional OLS regressions for the two-day cumulative abnormal return $\operatorname{CAR}_{i, k}(-1,0)$ on key event dates, $k=1, \ldots, 5$ (Table 1). For every firm $i$, the daily average abnormal return $A R_{i, k}$ is calculated for each event $k$ employing the regression model in Table 4 . For each event $k$, the crosssectional OLS regression specification is shown below:

$$
\operatorname{CAR}_{i, k}(-1,0)=\alpha_{k}+\beta_{1, k} \text { Shortfall }_{i, k}+\beta_{2, k} \text { Controls }_{i, k}+\text { Industry }_{i}+\varepsilon_{i, k}
$$

Where Controls $_{i, k}$ is a vector of control variables defined in Appendix A. Industry $y_{i}$ controls for industry-fixed effects. Shortfall is replaced with Shortfall number $_{\text {in }}$ (the shortfall of independent director by number) in even-numbered columns. All variables are from the year-end prior to the event. Robust standard errors are reported in parenthesis. $*, * *, * *$ denote statistical significance at the $10 \%, 5 \%$ and $1 \%$ levels, respectively.

\begin{tabular}{|c|c|c|c|c|c|c|c|c|c|c|}
\hline \multirow[t]{2}{*}{ Event date $(k=1, \ldots, 5)$} & \multicolumn{2}{|c|}{ 22-Feb-2002 } & \multicolumn{2}{|c|}{ 11-Jan-2006 } & \multicolumn{2}{|c|}{ 28-Mar-2006 } & \multicolumn{2}{|c|}{ 22-Mar-2011 } & \multicolumn{2}{|c|}{ 31-Dec-2013 } \\
\hline & (1) & (2) & (3) & (4) & (5) & (6) & (7) & (8) & (9) & (10) \\
\hline Shortfall & $-0.085 * * *$ & & $-0.014 * * *$ & & $-0.065^{* *}$ & & $-0.082 * *$ & & $-0.023^{*}$ & \\
\hline & $(0.004)$ & & $(0.000)$ & & $(0.030)$ & & $(0.034)$ & & $(0.051)$ & \\
\hline Shortfall $_{\text {number }}$ & & $-0.009 * * *$ & & $-0.002 * * *$ & & $-0.005 * *$ & & $-0.008 * *$ & & $-0.003 *$ \\
\hline & & $(0.000)$ & & $(0.000)$ & & $(0.002)$ & & $(0.003)$ & & $(0.054)$ \\
\hline Controls & Yes & Yes & Yes & Yes & Yes & Yes & Yes & Yes & Yes & Yes \\
\hline Industry FE & Yes & Yes & Yes & Yes & Yes & Yes & Yes & Yes & Yes & Yes \\
\hline adj. R-sq & 0.121 & 0.121 & 0.154 & 0.162 & 0.090 & 0.112 & 0.263 & 0.265 & 0.419 & 0.442 \\
\hline$N$ (firms) & 640 & 640 & 640 & 640 & 106 & 106 & 232 & 232 & 302 & 302 \\
\hline
\end{tabular}




\section{Table 6}

Tobin's $Q$ and independent director shortfall: IV regressions

This table presents the OLS and the second-stage IV regression results of independent director shortfall on Tobin's Q. The second-stage IV regressions specification is displayed below:

$$
\text { Tobin's } Q_{i, t}=\alpha+\beta \text { Shortfall }{ }_{l, t}+\text { Firm }_{i}+\text { Year }_{t}+\varepsilon_{i, t}
$$

Where Shortfall $_{i, t}$ is the fitted value from the first-stage IV regressions:

$$
\text { Shortfall }_{i, t}=\alpha+\beta \text { Shortfall }_{i, T_{0}} \text { Year }_{t}+\text { Firm }_{i}+\text { Year }_{t}+\varepsilon_{i, t}
$$

Where Shortfall $i_{i, T_{0}}$ is firm $i$ 's (exogenous) regulation-induced shortfall of independent directors in fraction in base-year $T_{0}$, which is 2001 in this table. Firm $i$ and Year $_{t}$ control for firm- and year-fixed effects respectively. Shortfall is replaced with Shortfall $l_{\text {number }}$ (the number of independent director shortfall) in even-numbered columns. All variables are defined in Appendix A. Standard errors clustered by firm are reported in parenthesis. *, **, *** denote statistical significance at the $10 \%$,

\begin{tabular}{|c|c|c|c|c|c|c|c|c|c|c|c|c|}
\hline & \multicolumn{4}{|c|}{ All firms } & \multicolumn{4}{|c|}{$\begin{array}{c}\text { Firms with paid-up capital } \\
<50 \text { billion NTD }\end{array}$} & \multicolumn{4}{|c|}{$\begin{array}{l}\text { Firms with paid-up capital } \\
<10 \text { billion NTD }\end{array}$} \\
\hline & \multicolumn{4}{|c|}{ Sample period: 2002-2009 } & \multicolumn{4}{|c|}{ Sample period: $2002-2013$} & \multicolumn{4}{|c|}{ Sample period: $2002-2015$} \\
\hline & \multicolumn{2}{|c|}{ OLS } & \multicolumn{2}{|c|}{ IV } & \multicolumn{2}{|c|}{ OLS } & \multicolumn{2}{|c|}{ IV } & \multicolumn{2}{|c|}{ OLS } & \multicolumn{2}{|c|}{ IV } \\
\hline & $(1)$ & (2) & (3) & (4) & $(5)$ & (6) & $(7)$ & $(8)$ & $(9)$ & $(10)$ & $(11)$ & $(12)$ \\
\hline Shortfall & $\begin{array}{l}1.348 * * \\
(0.592)\end{array}$ & & $\begin{array}{c}1.694 * * * \\
(0.543)\end{array}$ & & $\begin{array}{l}1.714^{*} \\
(0.987)\end{array}$ & & $\begin{array}{l}1.958^{* *} \\
(0.776)\end{array}$ & & $\begin{array}{l}1.353 * * \\
(0.551)\end{array}$ & & $\begin{array}{c}1.786 * * * \\
(0.403)\end{array}$ & \\
\hline Shortfall $_{\text {number }}$ & & $\begin{array}{l}0.121^{*} \\
(0.065)\end{array}$ & & $\begin{array}{c}0.154 * * * \\
(0.029)\end{array}$ & & $\begin{array}{c}0.153 \\
(0.098)\end{array}$ & & $\begin{array}{l}0.184 * * \\
(0.076)\end{array}$ & & $\begin{array}{l}0.144 * \\
(0.088)\end{array}$ & & $\begin{array}{l}0.172 * * \\
(0.073)\end{array}$ \\
\hline Firm FE & Yes & Yes & Yes & Yes & Yes & Yes & Yes & Yes & Yes & Yes & Yes & Yes \\
\hline Year FE & Yes & Yes & Yes & Yes & Yes & Yes & Yes & Yes & Yes & Yes & Yes & Yes \\
\hline$F$-statistic & & & 63.097 & 69.324 & & & 79.361 & 82.433 & & & 120.328 & 101.892 \\
\hline$N$ (firm-years) & 4581 & 4581 & 4581 & 4581 & 5694 & 5694 & 5694 & 5694 & 3582 & 3582 & 3582 & 3582 \\
\hline
\end{tabular}
$5 \%$ and $1 \%$ levels, respectively. 


\section{Table 7}

\section{ASEA-induced changes in operating profitability}

This table presents the difference-in-difference (DID) regression results of operating profitability on the regulations. The estimation formula is listed below:

$$
\begin{aligned}
\text { ROA }_{i, t}=\alpha+ & \beta_{1} \text { Compliant Firms }_{i}+\beta_{2} \text { Post ASEA }_{t}+\beta_{3} \text { Compliant Firms }_{i} * \text { Post ASE }_{t} \\
& +\beta_{4} \text { Controls }_{i, t}+\beta_{5} \text { Firm }_{i}+\beta_{6} \text { Year }_{t}+\varepsilon_{i, t}
\end{aligned}
$$

Where our dependent variable $R O A_{i, t}$ is defined as the ratio of earnings before interest and tax to total assets, Firm $i$ and Year $_{t}$ control for firm- and year-fixed effects respectively. For the first ASEA enforcement in 2006, Compliant Firms $i$ is a dummy variable that equals 1 for listed firms with paid-up capital of more than 50 billion NTD before 2006, and 0 otherwise. Within a five-year window, Post ASEA $A_{t}$ is a dummy variable that equals 1 if in the post ASEA period, which is 20062010. For the second ASEA enforcement in 2011, Compliant Firms $s_{i}$ is a dummy variable that equals 1 for listed firms with paid-up capital ranging from 10 to 50 billion NTD before 2011, and 0 for those with paid-up capital of less than 10 billion NTD. Within a three-year window, Post ASEA $t$ is a dummy variable that equals 1 if in the post ASEA period, which is 2011-2013. All variables are defined in Appendix A. Standard errors clustered by firm are reported in parenthesis. *, **, *** denote

\begin{tabular}{|c|c|c|c|c|c|c|}
\hline \multirow[b]{3}{*}{ Dependent variable } & \multirow{2}{*}{\multicolumn{3}{|c|}{$\begin{array}{l}\text { The first ASEA enforcement } \\
\text { in } 2006 \\
\text { Sample period: } 2001-2010\end{array}$}} & \multirow{2}{*}{\multicolumn{3}{|c|}{$\begin{array}{l}\text { The second ASEA enforcement } \\
\text { in } 2011 \\
\text { Sample period: } 2008-2013\end{array}$}} \\
\hline & & & & & & \\
\hline & $\mathrm{ROA}_{\mathrm{t}}$ & $\mathrm{ROA}_{\mathrm{t}}$ & $\mathrm{ROA}_{\mathrm{t}+1}$ & $\mathrm{ROA}_{\mathrm{t}}$ & $\mathrm{ROA}_{\mathrm{t}}$ & $\mathrm{ROA}_{\mathrm{t}+1}$ \\
\hline & (1) & (2) & (3) & (4) & (5) & (6) \\
\hline \multirow[t]{2}{*}{ Compliant Firms } & 0.827 & & & 1.915 & & \\
\hline & (1.194) & & & $(1.253)$ & & \\
\hline \multirow[t]{2}{*}{ Post ASEA } & $-0.947 * * *$ & & & $-0.619 * * *$ & & \\
\hline & $(0.191)$ & & & $(0.191)$ & & \\
\hline \multirow[t]{2}{*}{$\begin{array}{l}\text { Compliant Firms } \\
* \text { Post ASEA }\end{array}$} & $-1.025 * *$ & $-1.039 * *$ & $-1.153 * *$ & $-1.256^{* * *}$ & $-1.213 * * *$ & $-1.316 * * *$ \\
\hline & $(0.429)$ & $(0.502)$ & $(0.582)$ & $(0.415)$ & $(0.410)$ & $(0.410)$ \\
\hline Controls & Yes & Yes & Yes & Yes & Yes & Yes \\
\hline Firm FE & No & Yes & Yes & No & Yes & Yes \\
\hline Year FE & No & Yes & Yes & No & Yes & Yes \\
\hline adj. R-sq & 0.180 & 0.129 & 0.133 & 0.184 & 0.128 & 0.132 \\
\hline$N$ (firm-years) & 5755 & 5755 & 5109 & 2832 & 2832 & 2267 \\
\hline
\end{tabular}
statistical significance at the $10 \%, 5 \%$ and $1 \%$ levels, respectively. 
Table 8

ASEA-induced changes in operating profitability: robustness checks 1

This table reports the empirical results of the first two robustness checks regarding the arguably causal relation between ASEA-induced changes of independent directors and operating profitability by employing difference-in-difference estimations. Panel A reports regression results using a matched sample. Panel B reports regression results using a sample that excludes firms with paid-up capital that falls within a range of $10 \%$ above or below the regulatory thresholds before the ASEAs come into effect. All variables are defined in Appendix A. Standard errors clustered by firm are reported in parenthesis. *, **,*** denote statistical significance at the $10 \%, 5 \%$ and $1 \%$ levels, respectively.

\begin{tabular}{|c|c|c|c|c|}
\hline \multirow{3}{*}{ Panel A: Matched sample } & \multirow{2}{*}{\multicolumn{2}{|c|}{$\begin{array}{l}\text { The first ASEA enforcement } \\
\text { in } 2006 \\
\text { Sample period: } 2001-2010\end{array}$}} & \multirow{2}{*}{\multicolumn{2}{|c|}{$\begin{array}{l}\text { The second ASEA enforcement } \\
\text { in } 2011 \\
\text { Sample period: } 2008-2013\end{array}$}} \\
\hline & & & & \\
\hline & & & & \\
\hline \multirow[t]{2}{*}{ Dependent variable } & $\mathrm{ROA}_{\mathrm{t}}$ & $\mathrm{ROA}_{\mathrm{t}+1}$ & $\mathrm{ROA}_{\mathrm{t}}$ & $\mathrm{ROA}_{\mathrm{t}+1}$ \\
\hline & (1) & (2) & (3) & (4) \\
\hline \multirow[t]{2}{*}{$\begin{array}{l}\text { Compliant Firms } \\
* \text { Post ASEA }\end{array}$} & $-0.810^{* * *}$ & $-0.863 * * *$ & $-0.968 * * *$ & $-0.882 * *$ \\
\hline & $(0.298)$ & $(0.320)$ & $(0.336)$ & $(0.422)$ \\
\hline Controls & Yes & Yes & Yes & Yes \\
\hline Firm FE & Yes & Yes & Yes & Yes \\
\hline Year FE & Yes & Yes & Yes & Yes \\
\hline adj. R-sq & 0.178 & 0.132 & 0.201 & 0.141 \\
\hline$N$ (firm-years) & 1912 & 1719 & 2402 & 1991 \\
\hline \multicolumn{5}{|c|}{ Panel B: Sample excluding firms with paid-up capital close to the regulatory thresholds } \\
\hline \multirow[t]{2}{*}{ Dependent variable } & $\mathrm{ROA}_{\mathrm{t}}$ & $\mathrm{ROA}_{\mathrm{t}+1}$ & $\mathrm{ROA}_{\mathrm{t}}$ & $\mathrm{ROA}_{\mathrm{t}+1}$ \\
\hline & (1) & (2) & (3) & (4) \\
\hline \multirow[t]{2}{*}{$\begin{array}{l}\text { Compliant Firms } \\
* \text { Post ASEA }\end{array}$} & $-0.839 * * *$ & $-0.933 * *$ & $-1.052 * * *$ & $-1.173^{* *}$ \\
\hline & $(0.314)$ & $(0.412)$ & $(0.332)$ & $(0.490)$ \\
\hline Controls & Yes & Yes & Yes & Yes \\
\hline Firm FE & Yes & Yes & Yes & Yes \\
\hline Year FE & Yes & Yes & Yes & Yes \\
\hline adj. R-sq & 0.183 & 0.190 & 0.182 & 0.197 \\
\hline$N$ (firm-years) & 5487 & 4942 & 2674 & 2194 \\
\hline
\end{tabular}


Table 9

ASEA-induced changes in operating profitability: robustness checks 2

This table reports the empirical results of the last two robustness checks regarding the arguably causal relation between ASEA-induced changes of independent directors and operating profitability by employing difference-in-difference estimations. Panel A reports regression results based on 'pseudoevent' firms. Pseudo-event Firms is a dummy variable that equals 1 if the firms have paid-up capital ranging from 40 to 50 billion NTD before the first ASEA period or from 8 to 10 billion NTD before the second ASEA period. The observations regarding the actual compliant firms to these two ASEA enforcements are excluded respectively. Panel B reports results based on 'pseudo-event' years. Pseudo-post ASEA is a dummy variable that equals 1 if the year is one year before the ASEAs come into effect. All variables are defined in Appendix A. Standard errors clustered by firm are reported in parenthesis. $*, * *, * * *$ denote statistical significance at the $10 \%, 5 \%$ and $1 \%$ levels, respectively.

The first ASEA enforcement in 2006

Sample period: $2001-2010$

The second ASEA enforcement

\begin{tabular}{|c|c|c|c|c|}
\hline \multirow{2}{*}{ Panel A: Pseudo-event firms } & \multicolumn{2}{|c|}{ in 2006} & \multicolumn{2}{|c|}{ in 2011} \\
\hline & & & & \\
\hline \multirow[t]{2}{*}{ Dependent variable } & $\mathrm{ROA}_{t}$ & $\mathrm{ROA}_{t+1}$ & $\mathrm{ROA}_{t}$ & $\mathrm{ROA}_{t+1}$ \\
\hline & $(1)$ & (2) & $(3)$ & (4) \\
\hline \multirow[t]{2}{*}{$\begin{array}{l}\text { Pseudo-event Firms } \\
\text { * Post ASEA }\end{array}$} & -0.836 & -0.931 & -0.929 & -1.026 \\
\hline & $(0.781)$ & $(0.814)$ & $(0.982)$ & $(0.991)$ \\
\hline Controls & Yes & Yes & Yes & Yes \\
\hline Firm FE & Yes & Yes & Yes & Yes \\
\hline Year FE & Yes & Yes & Yes & Yes \\
\hline adj. R-sq & 0.125 & 0.136 & 0.127 & 0.140 \\
\hline$N$ (firm-years) & 4814 & 4306 & 1632 & 1350 \\
\hline \multicolumn{5}{|c|}{ Panel B: Pseudo-event years } \\
\hline \multirow[t]{2}{*}{ Dependent variable } & $\mathrm{ROA}_{t}$ & $\mathrm{ROA}_{t+1}$ & $\mathrm{ROA}_{\mathrm{t}}$ & $\mathrm{ROA}_{\mathrm{t}+1}$ \\
\hline & (1) & (2) & (3) & (4) \\
\hline \multirow[t]{2}{*}{$\begin{array}{l}\text { Compliant Firms } \\
* \text { Pseudo-post ASEA }\end{array}$} & -0.826 & -0.893 & -0.886 & -0.964 \\
\hline & $(0.749)$ & $(0.773)$ & $(0.662)$ & $(0.932)$ \\
\hline Controls & Yes & Yes & Yes & Yes \\
\hline Firm FE & Yes & Yes & Yes & Yes \\
\hline Year FE & Yes & Yes & Yes & Yes \\
\hline adj. R-sq & 0.134 & 0.142 & 0.133 & 0.148 \\
\hline$N$ (firm-years) & 5755 & 5109 & 2832 & 2267 \\
\hline
\end{tabular}




\section{Table 10}

\section{ASEA-induced changes in board characteristics}

This table presents the difference-in-difference (DID) regression results of board characteristics on the regulations. The estimation formula is listed below:

Board Characteristics C $_{\text {, }}$

$=\alpha+\beta_{1}$ Compliant Firms $_{i}+\beta_{2}$ Post ASEA $_{t}+\beta_{3}$ Compliant Firms $_{i} *$ Post ASEA $_{t}+\beta_{4}$ Controls $_{i, t}+\beta_{5}$ Firm $_{i}+\beta_{6}$ Year $_{t}+\varepsilon_{i, t}$

Where our dependent variable Board Characteristics $s_{i, t}$ includes Board Size, the total number of board directors, Board Education, the average education level of board directors (We set 1, 2 and 3 for each director with a Bachelor's degree, a Master's degree and a PhD respectively, and 0 otherwise), Board Experience, the percentage of directors that expertise in finance, accounting or law, Board Compensation, the logarithm of the average compensation of a board, and Board Busyness, the percentage of directors with at least two board seats. Compliant Firms ${ }_{i}$ and Post ASEA $A_{t}$ are defined as the same as those in Table 7. Firm $i$ and Year control for firm- and year-fixed effects respectively. Due to the limited data, the results of board busyness are only available for the second ASEA. All variables are defined in Appendix A. Standard errors clustered by firm are reported in parenthesis. *, **, *** denote statistical significance at the $10 \%, 5 \%$ and $1 \%$ levels, respectively.

\begin{tabular}{|c|c|c|c|c|c|c|c|c|c|}
\hline \multirow[b]{3}{*}{$\begin{array}{l}\text { Dependent } \\
\text { variable }\end{array}$} & \multicolumn{4}{|c|}{ The first ASEA enforcement in 2006} & \multicolumn{5}{|c|}{ The second ASEA enforcement in 2011} \\
\hline & \multicolumn{4}{|c|}{ Sample period: $2001-2010$} & \multicolumn{5}{|c|}{ Sample period: $2008-2013$} \\
\hline & Board Size & $\begin{array}{c}\text { Board } \\
\text { Education }\end{array}$ & $\begin{array}{c}\text { Board } \\
\text { Experience }\end{array}$ & $\begin{array}{c}\text { Board } \\
\text { Compensation }\end{array}$ & Board Size & $\begin{array}{c}\text { Board } \\
\text { Education }\end{array}$ & $\begin{array}{c}\text { Board } \\
\text { Experience }\end{array}$ & $\begin{array}{c}\text { Board } \\
\text { Compensation }\end{array}$ & Board Busyness \\
\hline & (1) & (2) & (3) & (4) & (5) & (6) & (7) & (8) & (9) \\
\hline $\begin{array}{l}\text { Compliant Firms } \\
* \text { Post ASEA }\end{array}$ & -1.077 & $0.070^{*}$ & 0.029 & $0.377^{* *}$ & -0.242 & 0.064 & 0.018 & $0.421 * *$ & $0.194 * * *$ \\
\hline & $(0.951)$ & $(0.038)$ & $(0.025)$ & $(0.179)$ & $(0.234)$ & $(0.058)$ & $(0.013)$ & $(0.173)$ & $(0.034)$ \\
\hline Controls & Yes & Yes & Yes & Yes & Yes & Yes & Yes & Yes & Yes \\
\hline Firm FE & Yes & Yes & Yes & Yes & Yes & Yes & Yes & Yes & Yes \\
\hline Year FE & Yes & Yes & Yes & Yes & Yes & Yes & Yes & Yes & Yes \\
\hline adj. R-sq & 0.162 & 0.169 & 0.124 & 0.108 & 0.165 & 0.172 & 0.136 & 0.112 & 0.121 \\
\hline$N$ (firm-years) & 5753 & 5752 & 5752 & 5675 & 2831 & 2830 & 2830 & 2816 & 2826 \\
\hline
\end{tabular}


Appendix A

Definitions of variables

\begin{tabular}{|c|c|}
\hline Variable name & Definition \\
\hline \multicolumn{2}{|c|}{ Firm value measures } \\
\hline Tobin's Q & $\begin{array}{l}\text { The sum of market value of equity and the book value of debt divided by } \\
\text { the book value of assets. }\end{array}$ \\
\hline ROA & The ratio of earnings before interest and tax to total assets. \\
\hline \multicolumn{2}{|c|}{$\begin{array}{l}\text { Independent director } \\
\text { measures }\end{array}$} \\
\hline Shortfall & $\begin{array}{l}\text { The difference between the percentage of independent directors required by } \\
\text { the regulations (Table 1) and the actual percentage of independent directors. }\end{array}$ \\
\hline Shortfall $_{\text {number }}$ & $\begin{array}{l}\text { The difference between the number of independent directors required by } \\
\text { the regulations (Table 1) and the actual number of independent directors. }\end{array}$ \\
\hline & $\begin{array}{l}\text { For Event } 3 \text {, it is a dummy variable that equals } 1 \text { for listed firms with paid- } \\
\text { up capital of more than } 50 \text { billion NTD before } 2006 \text {, and } 0 \text { otherwise. For }\end{array}$ \\
\hline Compliant Firms & $\begin{array}{l}\text { Event } 4 \text {, it is a dummy variable that equals } 1 \text { for listed firms with paid-up } \\
\text { capital ranging from } 10 \text { to } 50 \text { billion NTD, and } 0 \text { for those with paid-up } \\
\text { capital of less than } 10 \text { billion NTD. }\end{array}$ \\
\hline Pseudo-event Firms & $\begin{array}{l}\text { For Event } 3 \text {, it is a dummy variable that equals } 1 \text { if the firm has paid-up } \\
\text { capital ranging from } 40 \text { to } 50 \text { billion NTD before the first ASEA period, } \\
\text { and } 0 \text { if the firm has paid-up capital less than } 40 \text { billion NTD. For Event } 4 \text {, } \\
\text { it is a dummy variable that equals } 1 \text { if the firms have paid-up capital ranging } \\
\text { from } 8 \text { to } 10 \text { billion NTD before the second ASEA period, and } 0 \text { if the firms } \\
\text { have paid-up capital less than } 8 \text { billion NTD. }\end{array}$ \\
\hline Post ASEA & $\begin{array}{l}\text { For Event } 3 \text {, it is a dummy variable that equals } 1 \text { if in the post ASEA period, } \\
\text { which is } 2006 \text {. For Event } 4 \text {, it is a dummy variable that equals } 1 \text { if in the } \\
\text { post ASEA period, which is } 2011 \text {. }\end{array}$ \\
\hline Pseudo-post ASEA & $\begin{array}{l}\text { It is a dummy variable that equals } 1 \text { if the year is one year before the ASEAs } \\
\text { came into effect. }\end{array}$ \\
\hline \multicolumn{2}{|l|}{ Control variables } \\
\hline Board Size & The total number of board directors. \\
\hline CEO Duality & $\begin{array}{l}\text { A dummy variable that equals } 1 \text { if the CEO is also the chairman of the } \\
\text { board. }\end{array}$ \\
\hline Total Assets & The logarithm of total assets. \\
\hline Leverage & Total debt over total assets. \\
\hline Ownership \% & $\begin{array}{l}\text { The percentage of shares owned by ultimate shareholders (industrial } \\
\text { companies and families) who control either directly or indirectly through } \\
\text { affiliated firms. }\end{array}$ \\
\hline Board Education & $\begin{array}{l}\text { The average education level of board directors (We set } 1,2 \text { and } 3 \text { for each } \\
\text { director with a Bachelor's degree, a Master's degree and a } \mathrm{PhD} \\
\text { respectively, and } 0 \text { otherwise). }\end{array}$ \\
\hline
\end{tabular}


The percentage of directors that are financial, accounting or legal experts. We classify a director as a financial or accounting expert if he or she (i) has the working experience in a banking institution, (ii) has the working

Board Experience

Board Compensation

Board Busyness experience in a non-banking institution, (iii) has played a finance- or accounting-related role within a non-financial firm (e.g., CFO, accountant, auditor, treasurer, or Vice President for Finance and Accounting). We classify a director as a legal expert if he or she has the working experience as a legal counsel, attorney or judge.

The logarithm of the average compensation (salary plus bonus) of a board. The percentage of directors with at least two board seats. 


\section{Appendix B}

Abnormal stock returns to Taiwanese listed firms on five-day window of key event dates

This table presents cumulative abnormal returns, $\operatorname{CAR}(-2,2)=5 A R_{k}$, for portfolios of listed firms in Taiwan on the key event date $k$, estimated using the calculation formula in Table 4 . We redefine the dummy variable $D_{d k}$ to equal 1 for each day in the five-day event window $(-2,2)$ and 0 otherwise. Events $k=1, \ldots, 5$ are defined in Table 1. Firms with Zero are firms with no independent directors before the events, while firms with Pos are firms with independent directors before the events. *, **, $* * *$ denote statistical significance at the $10 \%, 5 \%$ and $1 \%$ levels, respectively.

$\begin{array}{cccc} & \text { Firms with } & \text { Firms with } & \text { Mean } \\ \text { All firms } & \text { Zero } & \text { Pos } & \text { Difference } \\ & & & \text { Zero }- \text { Pos }\end{array}$
(1)
(2)
(3)
(4)

(1) February 22, 2002: IPO firms

$\begin{array}{lcccc}C A R_{I}(-2,2)=5 A R_{I} & -0.024 * * & -0.027 * * & -0.018 * * * & -0.009 * * \\ p \text {-value } & (0.035) & (0.021) & (0.002) & (0.026) \\ N \text { (firms) } & 640 & 563 & 77 & \end{array}$

(2) January 11, 2006: the Amendment of Security and Exchange Act (ASEA)

$\begin{array}{lcccc}C A R_{2}(-2,2)=5 A R_{2} & -0.008 * * * & -0.010^{* * *} & -0.003^{* *} & -0.007 * * \\ p \text {-value } & (0.008) & (0.006) & (0.034) & (0.026) \\ N \text { (firms) } & 640 & 534 & 106 & \end{array}$

(3) March 28, 2006: firms with paid-up capital of more than 50 billion NTD

$\begin{array}{lcccc}C A R_{3}(-2,2)=5 A R_{3} & -0.020^{* *} & -0.021 * * & -0.017 * & -0.004 * \\ p \text {-value } & (0.041) & (0.042) & (0.054) & (0.059) \\ N \text { (firms) } & 106 & 83 & 23 & \end{array}$

(4) March 22, 2011: firms with paid-up capital of 10 50 billion NTD

$\begin{array}{lcccc}C A R_{4}(-2,2)=5 A R_{4} & -0.046^{* *} & -0.051^{* *} & -0.035^{* *} & -0.016^{* *} \\ p \text {-value } & (0.048) & (0.045) & (0.037) & (0.021)\end{array}$

$N$ (firms) $\quad 232 \quad 178 \quad 54$

(5) December 31, 2013: firms with paid-up capital of less than 10 billion NTD

\begin{tabular}{lcccc}
$C A R_{5}(-2,2)=5 A R_{5}$ & $-0.014^{* *}$ & $-0.016^{* *}$ & $-0.011^{*}$ & $-0.005^{*}$ \\
$p$-value & $(0.048)$ & $(0.035)$ & $(0.061)$ & $(0.061)$ \\
$N$ (firms) & 302 & 220 & 82 & \\
\hline
\end{tabular}




\section{Appendix C}

IV regressions for Tobin's $Q$ and independent director shortfall: the first-stage results

This table presents estimates of the coefficient $\beta$ from the first-stage instrumental variable (IV) regressions:

$$
\text { Shortfall }_{i, t}=\alpha+\beta \text { Shortfall }_{i, T_{0}} \text { Year }_{t}+\text { Firm }_{i}+\text { Year }_{t}+\varepsilon_{i, t}
$$

Where Shortfall ${ }_{i, T_{0}}$ is firm $i$ 's (exogenous) regulation-induced shortfall of independent directors in fraction in base-year $T_{0}$, Firm $_{i}$ and Year $_{t}$ control for firm-

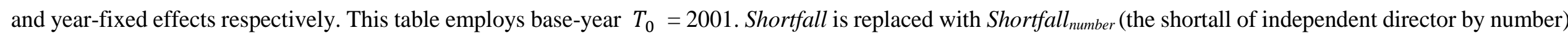
in even-numbered columns. All variables are defined in Appendix A. Standard errors clustered by firm are reported in parenthesis. *, **,*** denote statistical significance at the $10 \%, 5 \%$ and $1 \%$ levels, respectively.

\begin{tabular}{|c|c|c|c|c|c|c|}
\hline & \multicolumn{2}{|c|}{ All firms } & \multicolumn{2}{|c|}{$\begin{array}{l}\text { Firms with paid-up capital } \\
<50 \text { billion NTD }\end{array}$} & \multicolumn{2}{|c|}{$\begin{array}{l}\text { Firms with paid-up capital } \\
<10 \text { billion NTD }\end{array}$} \\
\hline & \multicolumn{2}{|c|}{$\begin{array}{c}\text { Sample period: } 2002-2009 \\
T_{0}=2001\end{array}$} & \multicolumn{2}{|c|}{$\begin{array}{c}\text { Sample period: } 2002-2013 \\
T_{0}=2001\end{array}$} & \multicolumn{2}{|c|}{$\begin{array}{c}\text { Sample period: } 2002-2015 \\
T_{0}=2001\end{array}$} \\
\hline & (1) & (2) & (3) & (4) & (5) & (6) \\
\hline Shortfall $T_{0} \times$ Year2002 & $\begin{array}{c}0.714 * * * \\
(0.040)\end{array}$ & $\begin{array}{c}0.786 * * * \\
(0.037)\end{array}$ & $\begin{array}{c}0.755 * * * \\
(0.033)\end{array}$ & $\begin{array}{c}0.741 * * * \\
(0.031)\end{array}$ & $\begin{array}{c}0.711 * * * \\
(0.040)\end{array}$ & $\begin{array}{c}0.736^{* * * *} \\
(0.040)\end{array}$ \\
\hline Shortfall $\mathrm{T}_{0} \times$ Year2003 & $\begin{array}{c}0.680 * * * \\
(0.026)\end{array}$ & $\begin{array}{c}0.638 * * * \\
(0.025)\end{array}$ & $\begin{array}{c}0.682 * * * \\
(0.025)\end{array}$ & $\begin{array}{c}0.653 * * * \\
(0.023)\end{array}$ & $\begin{array}{c}0.665^{* * *} \\
(0.033)\end{array}$ & $\begin{array}{c}0.644 * * * \\
(0.030)\end{array}$ \\
\hline Shortfall $\mathrm{T}_{0} \times$ Year2004 & $\begin{array}{c}0.575 * * * \\
(0.022)\end{array}$ & $\begin{array}{c}0.536^{* * * *} \\
(0.019)\end{array}$ & $\begin{array}{c}0.539 * * * \\
(0.021)\end{array}$ & $\begin{array}{c}0.515^{* * * *} \\
(0.019)\end{array}$ & $\begin{array}{c}0.567 * * * \\
(0.028)\end{array}$ & $\begin{array}{c}0.551 * * * \\
(0.025)\end{array}$ \\
\hline Shortfall $\mathrm{T}_{0} \times$ Year2005 & $\begin{array}{c}0.395 * * * \\
(0.020)\end{array}$ & $\begin{array}{c}0.364 * * * \\
(0.019)\end{array}$ & $\begin{array}{c}0.358 * * * \\
(0.020)\end{array}$ & $\begin{array}{c}0.334 * * * \\
(0.019)\end{array}$ & $\begin{array}{c}0.389 * * * \\
(0.024)\end{array}$ & $\begin{array}{c}0.372 * * * * \\
(0.021)\end{array}$ \\
\hline Shortfall $\mathrm{T}_{0} \times$ Year2006 & $\begin{array}{c}0.180 * * * \\
(0.019)\end{array}$ & $\begin{array}{c}0.175 * * * \\
(0.016)\end{array}$ & $\begin{array}{c}0.162^{* * *} \\
(0.019)\end{array}$ & $\begin{array}{c}0.145^{* * *} \\
(0.017)\end{array}$ & $\begin{array}{c}0.155^{* * *} \\
(0.021)\end{array}$ & $\begin{array}{c}0.152 * * * \\
(0.021)\end{array}$ \\
\hline Shortfall $\mathrm{T}_{0} \times$ Year2007 & $0.074 * * *$ & $0.065^{* * *}$ & $0.081 * * *$ & $0.087 * * *$ & $0.080 * * *$ & $0.065^{* * *}$ \\
\hline
\end{tabular}




\begin{tabular}{|c|c|c|c|c|c|c|}
\hline & $(0.019)$ & $(0.016)$ & $(0.017)$ & $(0.015)$ & $(0.018)$ & $(0.018)$ \\
\hline \multirow[t]{2}{*}{ Shortfall $T_{0} \times$ Year2008 } & $0.021^{* *}$ & $0.019 * *$ & $0.028^{* *}$ & $0.023 * *$ & $0.021^{*}$ & $0.027 * *$ \\
\hline & $(0.010)$ & $(0.009)$ & $(0.013)$ & $(0.011)$ & $(0.013)$ & $(0.012)$ \\
\hline \multirow[t]{2}{*}{ Shortfall $\mathrm{T}_{0} \times$ Year2009 } & & & $0.012^{*}$ & $0.012 *$ & $0.016^{*}$ & $0.011^{*}$ \\
\hline & & & $(0.007)$ & $(0.007)$ & $(0.009)$ & $(0.007)$ \\
\hline \multirow[t]{2}{*}{ Shortfalli ${ }_{0} \times$ Year2010 } & & & 0.011 & 0.012 & 0.014 & 0.010 \\
\hline & & & $(0.008)$ & $(0.009)$ & $(0.009)$ & $(0.007)$ \\
\hline \multirow[t]{2}{*}{ Shortfall $T_{0} \times$ Year2011 } & & & $0.018^{*}$ & $0.019^{*}$ & 0.017 & 0.012 \\
\hline & & & $(0.011)$ & $(0.010)$ & $(0.015)$ & $(0.011)$ \\
\hline \multirow[t]{2}{*}{ Shortfall $\mathrm{T}_{0} \times$ Year2012 } & & & 0.004 & 0.003 & 0.017 & 0.016 \\
\hline & & & $(0.009)$ & $(0.08)$ & $(0.015)$ & $(0.011)$ \\
\hline \multirow[t]{2}{*}{ Shortfall $\mathrm{T}_{0} \times$ Year2013 } & & & & & 0.025 & 0.017 \\
\hline & & & & & $(0.017)$ & $(0.012)$ \\
\hline \multirow[t]{2}{*}{ Shortfall $\mathrm{T}_{0} \times$ Year2014 } & & & & & 0.011 & 0.009 \\
\hline & & & & & $(0.019)$ & $(0.014)$ \\
\hline Firm FE & Yes & Yes & Yes & Yes & Yes & Yes \\
\hline Year FE & Yes & Yes & Yes & Yes & Yes & Yes \\
\hline$F$-statistic & 49.313 & 43.481 & 47.426 & 40.803 & 50.902 & 48.388 \\
\hline$N$ (firm-years) & 4596 & 4596 & 5703 & 5703 & 3594 & 3594 \\
\hline
\end{tabular}




\section{Appendix D}

\section{Summary statistics for matching}

This table provides details of the samples that match compliant firms with non-compliant firms of the first ASEA enforcement and the second ASEA enforcement respectively. Using a one-to-one matching method without replacement, for each of compliant firms, we select one non-compliant firm that is closest to it based on observable characteristics, including a firm's board size, CEO duality, total assets, leverage, ownership \% and industry sector. Definitions of all variables are provided in Appendix A. *, **, $* * *$ denote statistical significance at the $10 \%, 5 \%$ and $1 \%$ level, respectively.

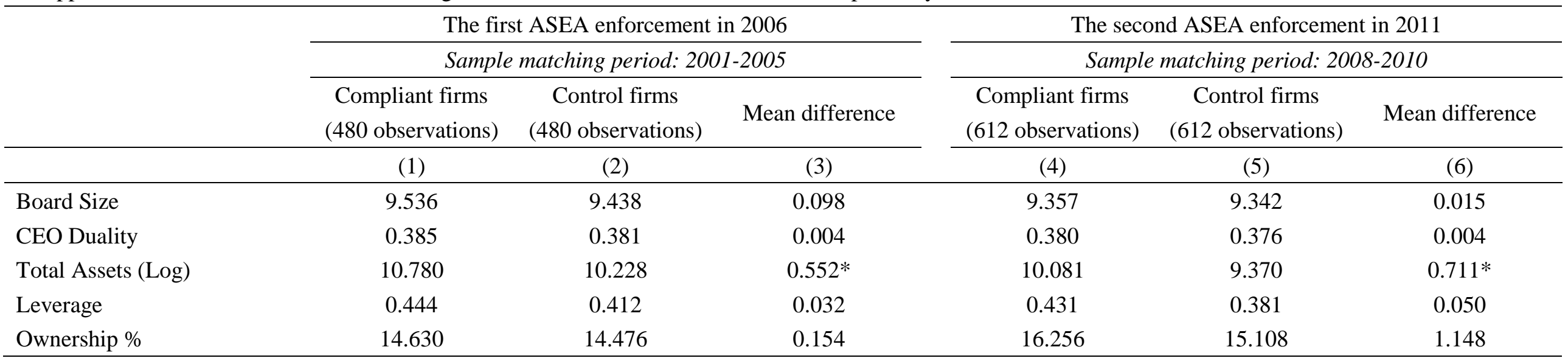


Figure 1

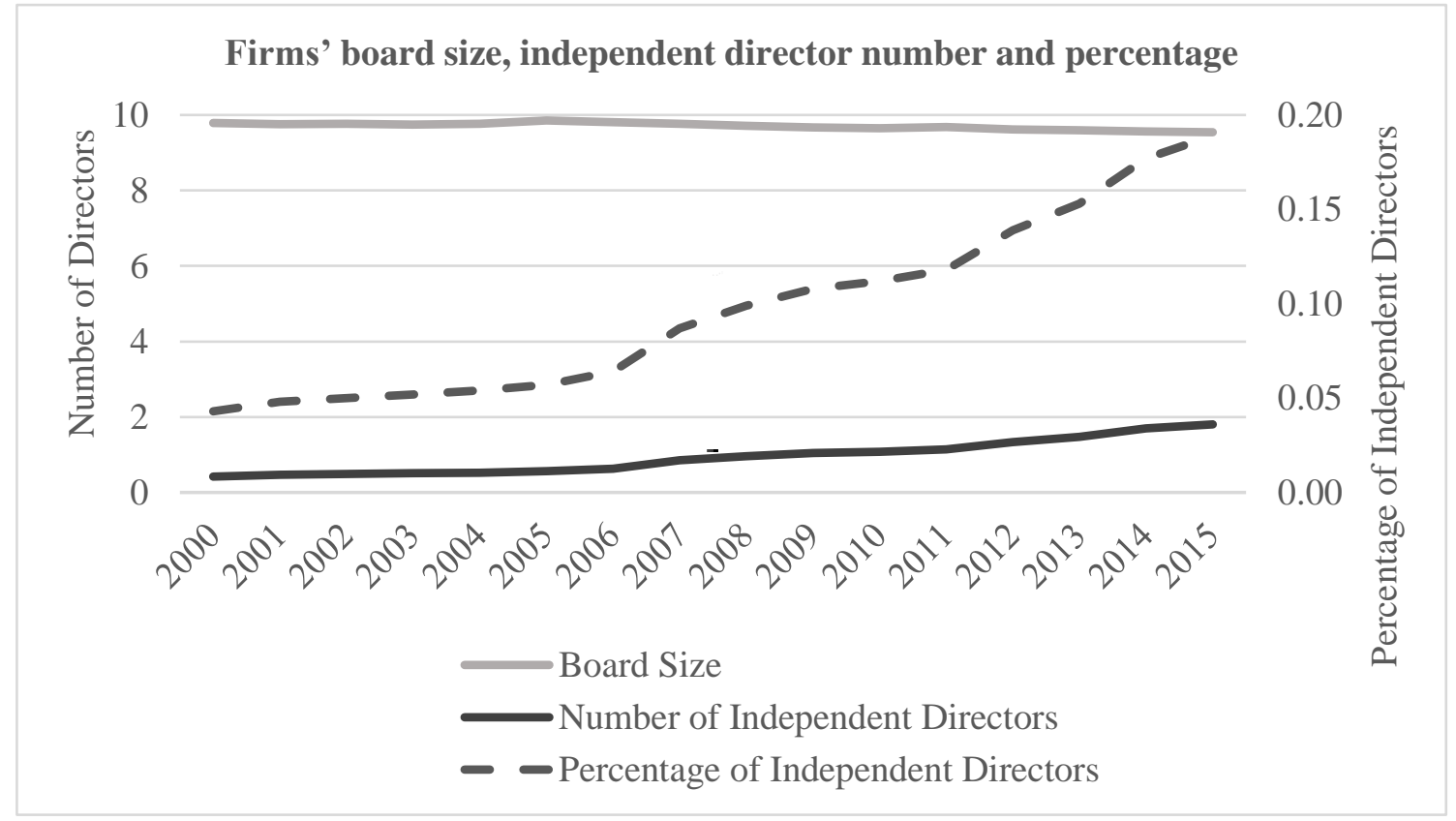

This figure plots the mean of board size, independent director number and percentage for Taiwanese firms from 2000 to 2015. The light line represents the trend of the mean of board size. The dark line represents the trend of the mean of the number of independent directors. The dotted line represents the trend of the mean of the percentage of independent directors.

Figure 2

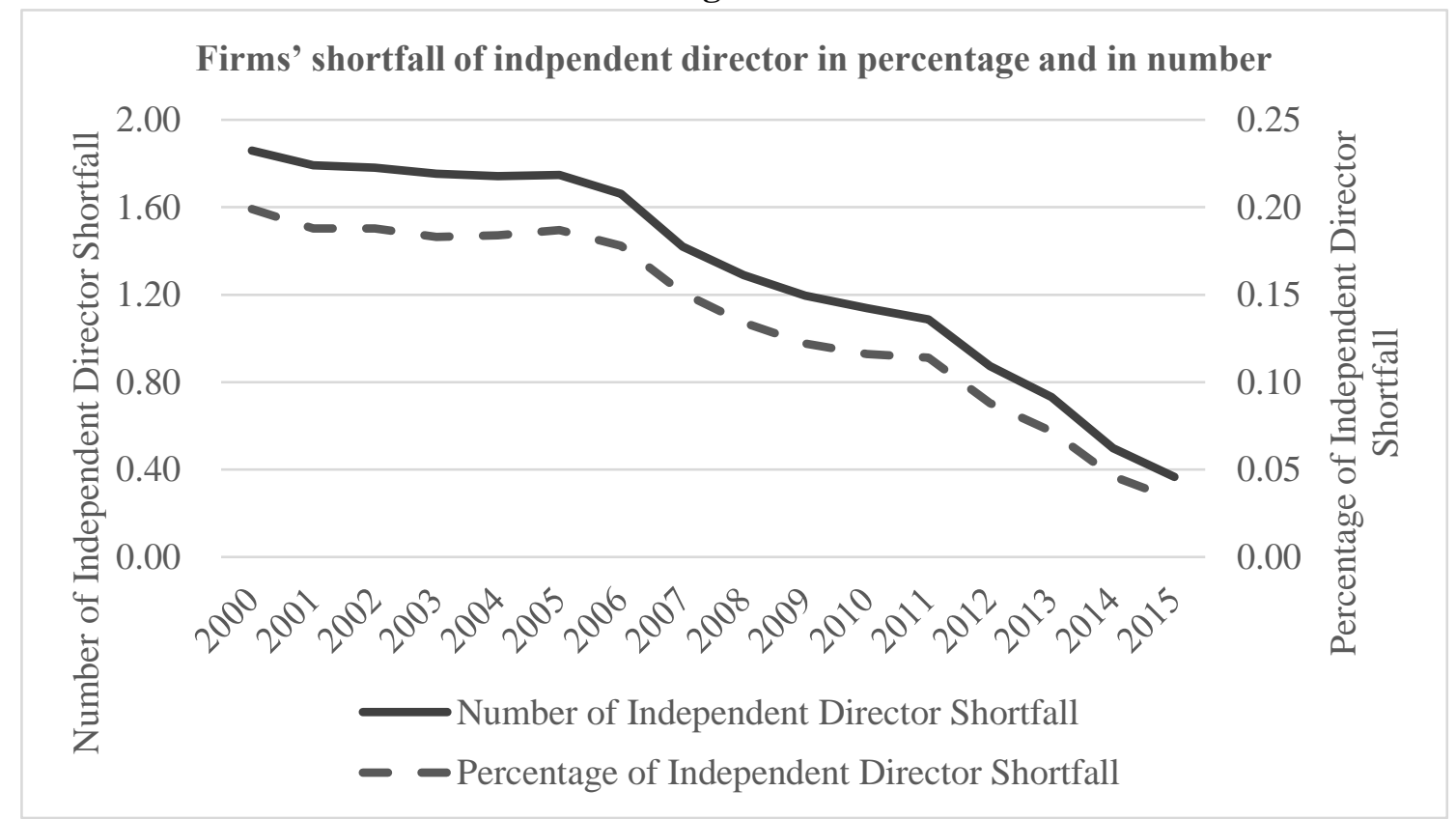

This figure plots the mean of the shortfall of independent directors in percentage and in number for Taiwanese firms from 2000 to 2015. The dark line represents the trend of the mean of the number of independent director shortfall. The dotted line represents the trend of the mean of the percentage of independent director shortfall. 
Figure 3

This figure plots the mean of board size, independent director number and fraction for firms with paidup capital of more than 50 billion NTD from 2000 to 2015 .

\section{Figure 4}

This figure plots the mean of board size, independent director number and fraction for firms with paidup capital of 10 50 billion NTD from 2000 to 2015.

\section{Figure 5}

This figure plots the mean of board size, independent director number and fraction for firms with paidup capital of less than 10 billion NTD from 2000 to 2015 .

Board size, independent director percentage and number of firms with paid-up capital of more than 50 billion NTD

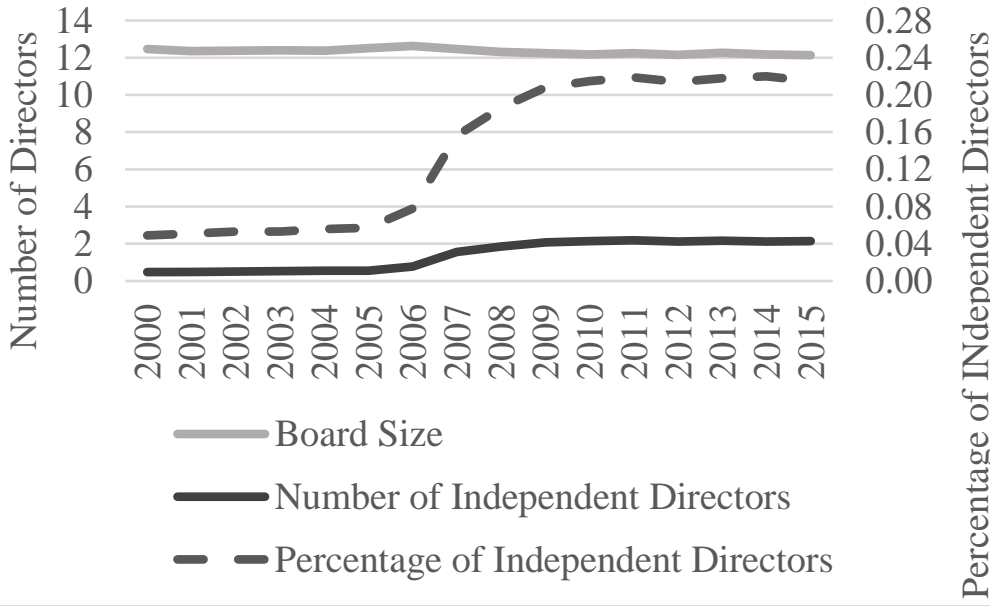

Board size, independent director percentage and number of firms with paid-up capital of 10 50 billion NTD

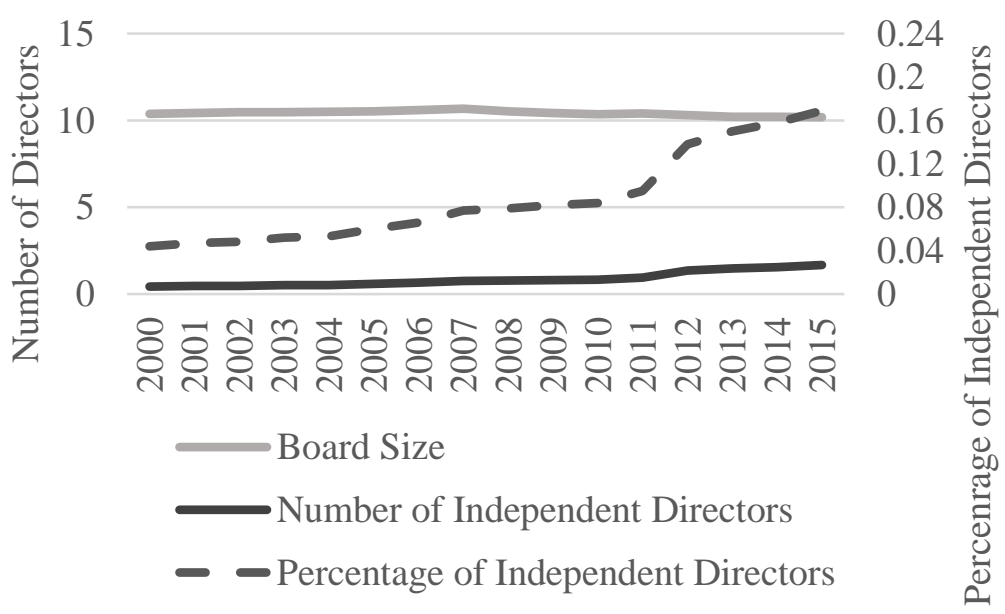

Board size, independent director percentage and number of firms with paid-up capital of less than 10 billion NTD

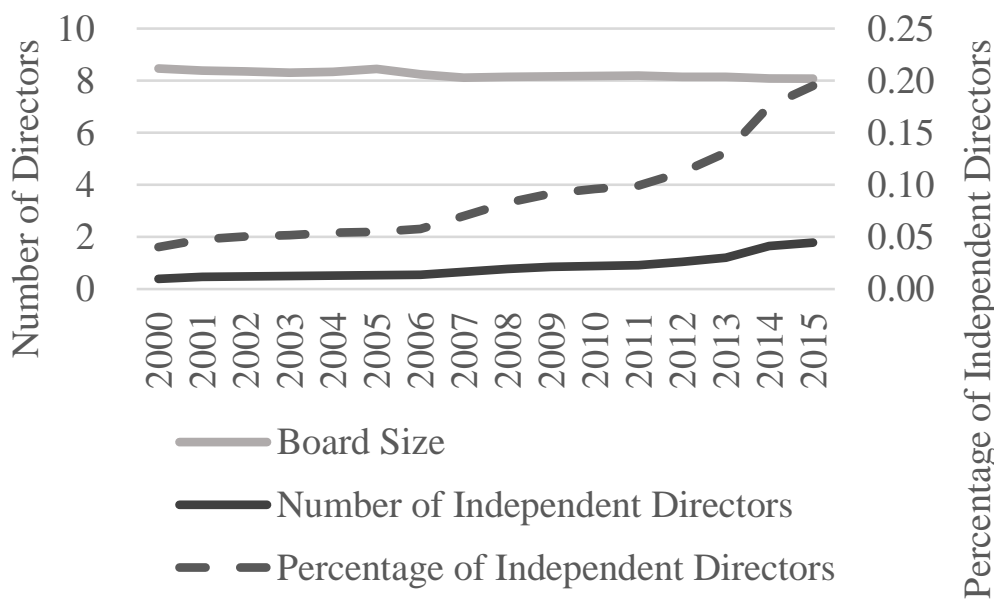

